\title{
Is It Possible to Create Antimicrobial Peptides Based on the Amyloidogenic Sequence of Ribosomal S1 Protein of $P$. aeruginosa?
}

\author{
Sergei Y. Grishin ${ }^{1}\left(\mathbb{D}\right.$, Pavel A. Domnin ${ }^{2,3,+}$, Sergey V. Kravchenko ${ }^{4,+}$, Viacheslav N. Azev ${ }^{5}$ (), Leila G. Mustaeva ${ }^{5}$, \\ Elena Y. Gorbunova ${ }^{5}$, Margarita I. Kobyakova ${ }^{6}$, Alexey K. Surin ${ }^{1,5,7}$, Maria A. Makarova ${ }^{7}$, Stanislav R. Kurpe ${ }^{1}$, \\ Roman S. Fadeev ${ }^{6}$, Alexey S. Vasilchenko ${ }^{4}{ }^{(D}$, Victoria V. Firstova ${ }^{7}$, Svetlana A. Ermolaeva ${ }^{2}$ (D) \\ and Oxana V. Galzitskaya ${ }^{1,6, *(1)}$
}

Citation: Grishin, S.Y.; Domnin, P.A. Kravchenko, S.V.; Azev, V.N.; Mustaeva, L.G.; Gorbunova, E.Y.; Kobyakova, M.I.; Surin, A.K.; Makarova, M.A.; Kurpe, S.R.; et al. Is It Possible to Create Antimicrobial Peptides Based on the Amyloidogenic Sequence of Ribosomal S1 Protein of P. aeruginosa? Int. J. Mol. Sci. 2021, 22, 9776. https://doi.org/10.3390/ ijms22189776

Academic Editor: Giovanna Batoni

Received: 16 August 2021

Accepted: 6 September 2021

Published: 10 September 2021

Publisher's Note: MDPI stays neutral with regard to jurisdictional claims in published maps and institutional affiliations.

Copyright: (c) 2021 by the authors. Licensee MDPI, Basel, Switzerland. This article is an open access article distributed under the terms and conditions of the Creative Commons Attribution (CC BY) license (https:// creativecommons.org/licenses/by/ $4.0 /)$.
1 Institute of Protein Research, Russian Academy of Sciences, 142290 Pushchino, Russia; syugrishin@gmail.com (S.Y.G.); alan@vega.protres.ru (A.K.S.); st.kurpe@gmail.com (S.R.K.)

2 Gamaleya Research Centre of Epidemiology and Microbiology, 123098 Moscow, Russia; paveldomnin6@gmail.com (P.A.D.); drermolaeva@mail.ru (S.A.E.)

3 Biology Faculty, Lomonosov Moscow State University, 119991 Moscow, Russia

4 Institute of Environmental and Agricultural Biology (X-BIO), Tyumen State University, 625003 Tyumen, Russia; svkraft@yandex.ru (S.V.K.); avasilchenko@gmail.com (A.S.V.)

5 The Branch of the Institute of Bioorganic Chemistry, Russian Academy of Sciences, 142290 Pushchino, Russia viatcheslav.azev@bibch.ru (V.N.A.); mustaeva@rambler.ru (L.G.M.); eyugorbunova@rambler.ru (E.Y.G.)

6 Institute of Theoretical and Experimental Biophysics, Russian Academy of Sciences, 142290 Pushchino, Russia; kobyakovami@gmail.com (M.I.K.); fadeevrs@gmail.com (R.S.F.)

7 State Research Center for Applied Microbiology and Biotechnology, 142279 Obolensk, Russia; mari.makar20@gmail.com (M.A.M.); victoria1@mail.ru (V.V.F.)

* Correspondence: ogalzit@vega.protres.ru; Tel.: +7-903-675-0156

$\dagger$ Equal contribution to the work.

Abstract: The development and testing of new antimicrobial peptides (AMPs) represent an important milestone toward the development of new antimicrobial drugs that can inhibit the growth of pathogens and multidrug-resistant microorganisms such as Pseudomonas aeruginosa, Gram-negative bacteria. Most AMPs achieve these goals through mechanisms that disrupt the normal permeability of the cell membrane, which ultimately leads to the death of the pathogenic cell. Here, we developed a unique combination of a membrane penetrating peptide and peptides prone to amyloidogenesis to create hybrid peptide: "cell penetrating peptide + linker + amyloidogenic peptide". We evaluated the antimicrobial effects of two peptides that were developed from sequences with different propensities for amyloid formation. Among the two hybrid peptides, one was found with antibacterial activity comparable to antibiotic gentamicin sulfate. Our peptides showed no toxicity to eukaryotic cells. In addition, we evaluated the effect on the antimicrobial properties of amino acid substitutions in the non-amyloidogenic region of peptides. We compared the results with data on the predicted secondary structure, hydrophobicity, and antimicrobial properties of the original and modified peptides. In conclusion, our study demonstrates the promise of hybrid peptides based on amyloidogenic regions of the ribosomal S1 protein for the development of new antimicrobial drugs against P. aeruginosa.

Keywords: ribosomal S1 protein; amyloid; antimicrobial peptides; Pseudomonas aeruginosa; cell penetrating peptide

\section{Introduction}

Currently, the development of new antimicrobial peptides (AMPs) is an important area for bioengineering and biomedical applications [1-3]. AMPs are created as molecules that selectively affect the basic bacterial functions or growth processes of pathogenic organisms. Over the past decade, several AMPs have been developed that can effectively act on pathogenic bacteria, fungi, or viruses [4-6]. 
New technologies have been demonstrated for the development of new antimicrobial peptides based on predicting candidate amino acid sequences in proteins, as implemented in Webservers as AmpGram [7], AMP Scanner [8], and CAMPR3 [9]. The task of developing new approaches to counteracting the spread of the pathogen is especially important for bacterial cells, such as P. aeruginosa, which play a role in the development of serious diseases and adaptively respond to many drugs, acquiring resistance to antibiotics [10-13]. Various methods for overcoming the problem of bacterial resistance are presented in the work of Shemyakin et al. [14]. The adaptive resistance of P. aeruginosa includes biofilm formation as a diffusion barrier restricting the access of antibiotics to bacterial cells [15,16]. In addition, the main resistance mechanisms include the low permeability of the outer membrane. OprF is the predominant porin of $P$. aeruginosa and is responsible for the nonspecific uptake of ions and saccharides, but has a low efficiency for antibiotic translocation $[17,18]$. Current therapeutic options for the treatment of $P$. aeruginosa include the use of various combinations of antibiotics and the development of new antibiotics and antimicrobial peptides, as well as their combinations $[19,20]$. The problem is that pathogenic microorganisms often adapt to the action of drugs, for example, synthesizing AAC $\left(6^{\prime}\right)$-I-type acetyltransferases, which catalyze the reaction of amikacin inactivation [21-23]. It has been shown that a wide range within efflux systems and mutations of $P$. aeruginosa strains evolutionarily increases the resistance of $P$. aeruginosa cells to antibiotics [24,25].

In this regard, amyloidogenic peptides are of interest, especially those that cause aggregation of ribosomal proteins and additionally disrupt the synthesis of bacterial proteins in general. Amyloidogenic peptides, alone or as part of combined preparations, can potentially be used to develop hybrid therapy for bacterial infections $[26,27]$. To achieve this goal, a deeper understanding of the mechanisms of action of peptides with amyloidogenic and antimicrobial properties is currently required [28-30]. The phenomenon of coaggregation of molecules, including those that act by the mechanism of directed coaggregation with a target lipid or protein, which is important for the function of antimicrobial peptides, is discussed in the recent scientific articles [31,32]. The mechanism of the transition of a protein from a native state to amyloid is not entirely clear. However, separate studies have examined bacterial amyloids [33]: amyloidogenesis of a prion-like protein was experimentally detected in E. coli using a fluorescent dye, and the RepA-WH1 protein formed cytotoxic aggregates that prevent bacterial growth [34]. The special attention should be paid to the use of the amyloidogenic properties of bacterial proteins for targeted protein aggregation [35]. The development of synthetic amyloidogenic peptides has been shown to be a promising approach to combat pathogenic bacteria [36,37]. At the same time, it should be borne in mind that bacteria have different mechanisms of counteracting protein aggregation, for example, by directing amyloids into inclusion bodies [35]. In addition, some bacteria are capable of using amyloids and amyloid-like protein structures in order to form biofilms [38,39]. Antimicrobial amyloidogenic peptides can be toxic not only to bacteria but also to eukaryotic cells. To avoid this, it is important to select a unique bacterial protein for induced amyloidosis in a bacterial cell and develop AMPs for this target.

We chose the ribosomal S1 protein as the target protein because this protein is unique to bacteria and is found as the largest bacterial ribosomal protein included in the $30 \mathrm{~S}$ ribosome subunit. S1 protein performs many functions: it is required for the initiation of translation of bacterial proteins and regulation of translation [40]. Bioinformatic studies of the family of ribosomal S1 protein have recently demonstrated that the number of domains in S1 proteins is a characteristic of the phylogenetic grouping of bacteria and can vary from one to six [41]. Each S1 domain has a number of functions that are still not well known; nevertheless, the domains are very similar in structure and consist of an OB-fold [42]. OB-fold is a $\beta$-barrel including five antiparallel $\beta$-strands and a single $\alpha$-helix. This fold is capable of performing a wide range of biological processes: control of RNA splicing, DNA repair, regulation of transcription, and many other functions $[43,44]$. The S1 domain can be found in different living organisms, and the number of S1 domains can vary from one to 15 [45]. The S1 protein from P. aeruginosa belongs to one of the largest classes of six-domain 
S1 proteins according to the server http:/ / oka.protres.ru:4200 (accessed on 7 September 2021) [46].

Amyloidogenic regions within the S1 domains of ribosomal S1 protein from P. aeruginosa were originally predicted using FoldAmyloid [47], Waltz [48], AGGRESCAN [49], and Pasta 2.0 [50], after which it was experimentally demonstrated that there amyloidogenic regions forms amyloid fibrils in vitro [51].

The relationship between amyloidogenic and antimicrobial properties plays an important role in the development of hybrid AMPs. Thus, it is known that amyloidogenic peptides, like antimicrobial peptides, can have a toxic effect on bacterial cells [52]. In addition, the amino acid sequences included in the spine of amyloid fibrils are sufficiently resistant to the action of proteases, which is one of the diagnostic properties of amyloid fibrils $[53,54]$. This resistance can also be useful for antimicrobial peptides, allowing them to be protected from the action of exopeptidases [55]. Typically, such hybrid peptides entail reciprocal biophysical and biochemical interactions that depend on the amino acid sequence, its mobility and hydrophobicity. The amino acid sequence is believed to play a key role in achieving the correct structure and function of antimicrobial peptides [56]. However, amyloidogenic peptides can have a toxic effects on eukaryotic cells $[57,58]$, which is an undesirable effect for the future use of AMPs in medicine [59]. Thus, the creation of a new generation of amyloidogenic-antimicrobial peptides requires studying how amyloidogenic and antimicrobial amino acid sequences can interact as part of a single molecule.

In accordance with the strategy presented in Figure 1, we developed hybrid peptides that contained a cell penetrating peptide (CPP) (fragment of Tat-peptide [60]) at the $\mathrm{N}$-termini and an amyloidogenic sequence at the C-termini, which was predicted using bioinformatics tools [51]. The two sites were linked by four glycines. Thus, the construction of the fusion peptide was as follows: "CPP"+"linker GGGG" + "predicted amyloidogenicfragment". The LHITDMAWKR and ITDFGIFIGL sequences were used as amyloidogenic fragments. Interestingly, although both of these sequences were predicted to be amyloidogenic, only the ITDFGIFIGL peptide exhibited amyloid-like properties according to electron microscopy and fluorescence of thioflavin T (ThT) under the condition studied [51]. In this paper, we tested the antimicrobial properties of the RKKRRQRRRGGGGLHITDMAWKR (R23R) and RKKRRQRRRGGGGITDFGIFIGL (R23L) peptides, as well as their analogs RKKRRQRRRGG-Sar-GLHITD-Nle-AWKR (R23R*) and RKKRRQRRRGG-SarGITDFGIFIGL (R23L*) to determine the possible effects associated with the replacement of glycine with sarcosine. In the R23R* peptide, methionine is replaced by norleucine, which is associated with the peculiarities of the R23R* peptide synthesis [61]. The antimicrobial properties of peptides can be seriously affected by a single point modification of a known sequence $[62,63]$. A similar approach based on the replacement of hydrophobic amino acid residues with sarcosine was used by other authors to show the importance of a stable conformation of the peptide for its antimicrobial action [64]. 


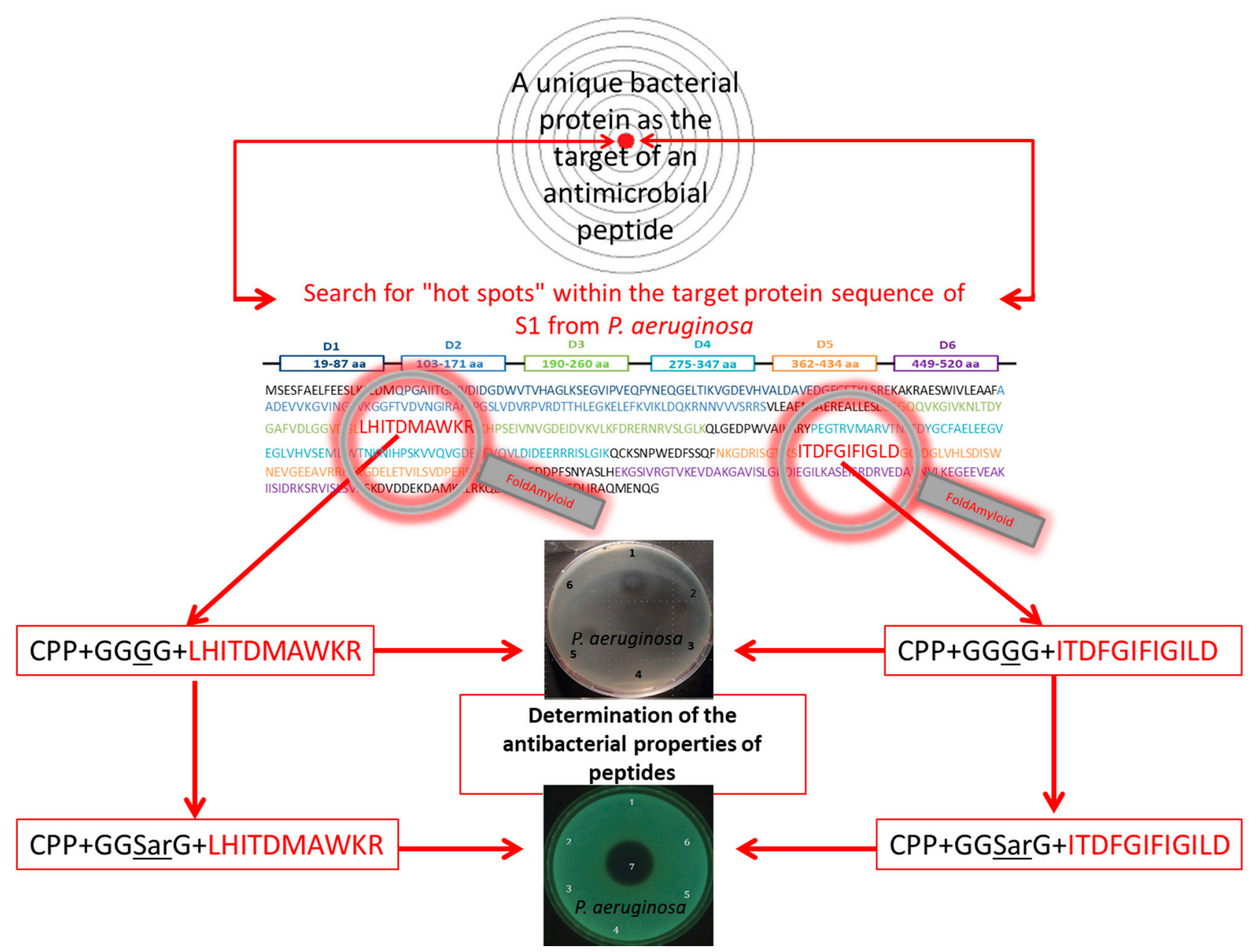

Figure 1. Schematic diagram of the creation of new AMPs (against P. aeruginosa) based on targeted protein aggregation. The domain organization of the S1 protein is shown schematically, each of the six protein domains (D1-D6) is color represented. The red font shows two amyloidogenic regions: LHITDMAWKR from the third domain and ITDFGIFIGLD from the fifth domain predicted by the FoldAmyloid and AGGRESCAN programs within the ribosomal S1 protein from P. aeruginosa [51]. The N-terminus of synthesized hybrid peptides contains a cell penetrating peptide (CPP) fragment RKKRRQRRR connected to the amyloidogenic region using a linker of four glycine residues (GGGG) or three glycine and sarcosine residues (GG-SarG). The hybrid AMPs with different concentrations can be tested against P. aeruginosa strains (see below "Materials and Methods" section).

\section{Results}

2.1. Prediction of the Secondary Structure and Antimicrobial Propensities of the R23R, R23L, R23R $R^{*}$, and $R 23 L^{*}$ Peptides

The effect of amino acid substitutions on the secondary structure and some physicochemical properties of the peptides can be predicted using special programs [65-67]. Theoretical information on ordered elements of the secondary structure of peptides, physicochemical properties of R23R, R23L, R23R*, and R23L*presented in Table 1. We used the JPred4 ("jnetpred" algorithm) and PredictProtein ("RePROF" algorithm) programs to predict the elements of the secondary structure of the R23R, R23L, R23R*, and R23L* peptides. Considering that sarcosine is not used for calculations in the algorithms of these bioinformatics tools, this amino acid residue in the original peptide sequence was replaced by alanine $(\mathrm{A})$ and proline $(\mathrm{P})$ residues which are similar in structure and properties to take into account the changes in the prediction results caused by the substitution of glycine 12 to sarcosine. 
Table 1. Prediction of the secondary structure $\S$ and physicochemical properties of the peptides.

\begin{tabular}{|c|c|c|c|c|c|c|}
\hline \multirow{2}{*}{ Peptide } & \multirow{2}{*}{ JPred4 (Jnetpred) } & \multirow{2}{*}{$\begin{array}{l}\text { Predict Protein } \\
\text { (RePROF) }\end{array}$} & \multicolumn{4}{|c|}{ DBAASP v3.0 (MF Scale) } \\
\hline & & & $\mu H_{n}$ & $\mathbf{H}_{\mathbf{n}}$ & $\mathbf{Z}$ & $\mathbf{I}_{0}$ \\
\hline \multicolumn{7}{|c|}{ R23R vs. R23R* } \\
\hline RKKRRQRRRGGGGLHITDMAWKR & $\begin{array}{l}\beta \text {-strand } 14-18 \text { a.a. } \\
\quad(\text { LHITD) }\end{array}$ & $\begin{array}{c}\text { Helix 2-9 a.a. } \\
\text { (KKRRQRRR), } \\
\text { 3-strand 14-18 a.a. } \\
\text { (LHITD) } \\
\text { Helix 2-9 a.a. }\end{array}$ & 0.36 & 0.91 & +9 & 12.51 \\
\hline $\begin{array}{c}\text { RKKRRQRRRGG-Sar } \\
\S \S(\mathrm{A})-\mathrm{GLHITD}-\mathrm{Nle} \$ \& \S(\mathrm{M})-\mathrm{AWKR}\end{array}$ & & $\begin{array}{c}\text { Helix } 2-9 \text { a.a. } \\
\text { (KKRRQRRR), other } \\
\text { 10-14 a.a. (GGAGL), } \\
\text { helix 18-22 (DMAWK) }\end{array}$ & 0.32 & 0.84 & +9 & 12.51 \\
\hline $\begin{array}{c}\text { RKKRRQRRRGG-Sar(A)-GLHITD- } \\
\text { Nle(L)-AWKR }\end{array}$ & $\begin{array}{c}\beta \text {-strand } 14-18 \text { a.a. } \\
\text { (LHITD) }\end{array}$ & $\begin{array}{c}\text { Helix 2-9 a.a. } \\
\text { (KKRRQRRR), other } \\
\text { 10-14 a.a. (GGAGL), } \\
\text { helix 18-22 (DMAWK) }\end{array}$ & 0.29 & 0.79 & +9 & 12.51 \\
\hline $\begin{array}{c}\text { RKKRRQRRRGG-Sar(P)-GLHITD- } \\
\text { Nle(M)-AWKR }\end{array}$ & & $\begin{array}{l}\text { Helix 2-9 a.a. } \\
\text { (KKRRQRRR), other } \\
\text { 10-14 a.a. (GGAGL) }\end{array}$ & 0.29 & 0.77 & +9 & 12.51 \\
\hline $\begin{array}{c}\text { RKKRRQRRRGG-Sar(P)-GLHITD- } \\
\text { Nle(L)-AWKR }\end{array}$ & & $\begin{array}{l}\text { Helix 2-9 a.a. } \\
\text { (KKRRQRRR), other } \\
\text { 10-14 a.a. (GGPGL) }\end{array}$ & 0.27 & 0.73 & +9 & 12.51 \\
\hline \multicolumn{7}{|c|}{ R23L vs. R23L* } \\
\hline RKKRRQRRRGGGGITDFGIFIGL & $\begin{array}{l}\beta \text {-strand } 17-21 \text { a.a. } \\
\quad \text { (FGIFI) }\end{array}$ & $\begin{array}{l}\text { (KRRQRRR), other } \\
\text { 10-15 a.a. (GGGGIT), } \\
\beta \text {-strand 16-21 a.a. } \\
\text { (DFGIFI) }\end{array}$ & 0.24 & 0.18 & +7 & 12.41 \\
\hline $\begin{array}{l}\text { RKKRRQRRRGG-Sar(A)- } \\
\text { GITDFGIFIGL }\end{array}$ & $\begin{array}{l}\beta \text {-strand } 17-21 \text { a.a. } \\
\quad \text { (FGIFI) }\end{array}$ & $\begin{array}{c}\text { Helix 3-9 a.a. } \\
\text { (KKRRQRRR), other } \\
\text { 10-15 a.a. (GGAGIT) }\end{array}$ & 0.18 & 0.11 & +7 & 12.41 \\
\hline $\begin{array}{l}\text { RKKRRQRRRGG-Sar(P)- } \\
\text { GITDFGIFIGL }\end{array}$ & $\begin{array}{l}\beta \text {-strand } 17-21 \text { a.a. } \\
\quad \text { (FGIFI) }\end{array}$ & $\begin{array}{c}\text { Helix 3-9 a.a. } \\
\text { (KKRRQRRR), other } \\
\text { 10-15 a.a. (GGPGIT) }\end{array}$ & 0.14 & 0.04 & +7 & 12.41 \\
\hline
\end{tabular}

$\S$ The predicted secondary structure elements of length $\geq 5$ a.a. $\$ \S$ For calculations, sarcosine (Sar) was replaced by analogs similar in properties and structure: alanine $(\mathrm{A})$ and proline $(\mathrm{P})$. $\& \& \$$ For calculations, norlecine (Nle) was replaced by analogs of similar properties and structure: methionine $(M)$ and leucine $(\mathrm{L}) . \mu \mathrm{H}_{\mathrm{n}}$ is the normalized hydrophobic moment, $\mathrm{H}_{\mathrm{n}}$ is the normalized hydrophobicity, $\mathrm{Z}$ is the value of charge at $\mathrm{pH} 7, \mathrm{I}_{0}$ is the value of isoelectric point.

As follows from the results of the predictions of the JPred4 and PredictProtein programs, substitution of position 12 glycine with sarcosine can lead to changes in the secondary structure of the modified R23R* and R23L* peptides. It was expected that replacing glycine with sarcosine would have a local effect on the secondary structure of the peptide, but this modification changed the results of predicting the secondary structure of the C-terminus of the peptide. According to the predictions we have a decrease in the $\beta$ structure of the modified peptides. At the same time, according to the data obtained using the DBAASP v3.0 database toolkit, the calculated $\mu \mathrm{H}_{n}$ and $\mathrm{H}_{\mathrm{n}}$ values tend to decrease. Moreover, it follows from Table 1 that $\mathrm{Z}$ and $\mathrm{I}_{0}$ of the peptide do not change due to the modification caused by the replacement of 12 glycine to sarcosine.

The CAMPR3 [9], AmpGram [7], and AMP Scanner [8] Webservers, predicting the antimicrobial properties of peptides using their secondary structure and physicochemical properties, can be used to develop AMPs. To achieve this goal, we first of all predicted their antimicrobial properties (Table 2). 
Table 2. Antimicrobial prediction for the R23R, R23L, R23L*, and R23L* peptides.

\begin{tabular}{|c|c|c|c|c|c|c|}
\hline \multirow[b]{2}{*}{ Peptide } & \multicolumn{4}{|c|}{ CAMPR3 } & \multirow{2}{*}{$\begin{array}{c}\text { AmpGram } \\
\begin{array}{c}\text { RF and } \\
\text { n-Grams }\end{array} \\
\end{array}$} & \multirow{2}{*}{$\begin{array}{c}\text { AMP Scanner } \\
\text { DNN }\end{array}$} \\
\hline & RF & SVM & ANN & DA & & \\
\hline \multicolumn{7}{|c|}{ R23R vs. R23R* } \\
\hline $\begin{array}{l}\text { RKKRRQRRRGGGGLHITD } \\
\text { MAWKR }\end{array}$ & $0.48($ non-AMP $\$)$ & 0.03 (non-AMP) & $\mathrm{AMP} \S \S$ & 0.93 (AMP) & 0.59 (AMP) & 0.07 (non-AMP) \\
\hline $\begin{array}{l}\text { RKKRRQRRRGG-Sar } \\
\& \& \&(\mathrm{~A})-\text { GLHITD-Nle } \\
\text { \&\&\&(M)-AWKR }\end{array}$ & 0.49 (non-AMP) & 0.03 (non-AMP) & AMP & 0.95 (AMP) & 0.54 (AMP) & 0.05 (non-AMP) \\
\hline $\begin{array}{l}\text { RKKRRQRRRGG-Sar(A)- } \\
\text { GLHITD-Nle(L)-AWKR }\end{array}$ & 0.58 (AMP) & 0.05 (non-AMP) & AMP & 0.96 (AMP) & 0.63 (AMP) & 0.03 (non-AMP) \\
\hline $\begin{array}{l}\text { RKKRRQRRRGG-Sar(P)- } \\
\text { GLHITD-Nle(M)-AWKR }\end{array}$ & 0.48 (non-AMP) & 0.04 (non-AMP) & non-AMP & 0.95 (AMP) & 0.47 (non-AMP) & 0.13 (non-AMP) \\
\hline $\begin{array}{l}\text { RKKRRQRRRGG-Sar(P)- } \\
\text { GLHITD-Nle(L)-AWKR }\end{array}$ & 0.53 (AMP) & 0.07 (non-AMP) & AMP & 0.97 (AMP) & 0.62 (AMP) & 0.07 (non-AMP) \\
\hline \multicolumn{7}{|l|}{ 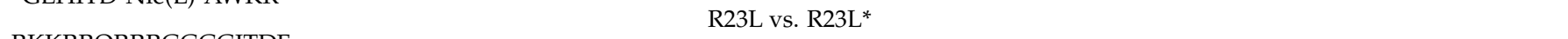 } \\
\hline $\begin{array}{l}\text { RKKRRQRRRGGGGITDF } \\
\text { GIFIGL }\end{array}$ & 0.59 (AMP) & 0.06 (non-AMP) & AMP & 1.00 (AMP) & 0.37 (non-AMP) & 0.93 (AMP) \\
\hline $\begin{array}{l}\text { RKKRRQRRRGG-Sar(A)- } \\
\text { GITDFGIFIGL }\end{array}$ & 0.59 (AMP) & 0.06 (non-AMP) & AMP & 1.00 (AMP) & 0.22 (non-AMP) & 0.44 (non-AMP) \\
\hline $\begin{array}{l}\text { RKKRRQRRRGG-Sar(P)- } \\
\text { GITDFGIFIGL }\end{array}$ & 0.58 (AMP) & 0.10 (non-AMP) & AMP & 1.00 (AMP) & 0.45 (non-AMP) & 0.95 (AMP) \\
\hline
\end{tabular}

$\S$ It is predicted as a peptide that does not exhibit antimicrobial activity. The prediction level is less than 0.5. $\$$ It is predicted as a peptide with antimicrobial activity. The prediction level is over than 0.5 . $\$ \$ \S$ For calculations, sarcosine (Sar) was replaced by analogs similar in properties and structure: alanine (A) and proline (P). $\$ \S \S \S$ For calculations, norlecine (Nle) was replaced by analogs of similar properties and structure: methionine (M) and leucine (L). Antimicrobial activity was predicted using algorithms: RF is a random forest, SVM is a support vector machine, ANN is an artificial neural network, DA is a discriminant analysis, RF and n-gramms is a random forest based on amino acid motifs, DNN is deep neural network.

The replacement of glycine 12 with sarcosine did not significantly alter the predictions of antimicrobial properties by the CAMPR3, AmpGram, and AMP Scanner web servers. R23L and R23L* were predicted as antimicrobial peptides practically by all programs with exception CAMPR3 (SVM) and AmpGram. AMP properties were not predicted for R23R and R23R* using CAMPR3 (SVM) and AMP Scanner. As we see further these predictions does coincide with the experimental validation.

\subsection{Experimental Validation of the Antibacterial Activity of Peptides}

\subsubsection{Determination of the Antibacterial Activity of Peptides on Agar}

In the next step, the predicted antimicrobial properties of the peptides were tested using agar experiments with P. aeruginosa strain PA103 cells (Figure 2).

The growth inhibition effects of $P$. aeruginosa cells were revealed for unmodified peptides R23R and R23L in the concentration ranges of 3600-3800 $\mu \mathrm{M}$ and 360-380 $\mu \mathrm{M}$. Thus, for the R23R and R23L peptides, the value of the minimum inhibitory concentration (MIC) was $360 \mu \mathrm{M}(1 \mathrm{mg} / \mathrm{mL})$ and $380 \mu \mathrm{M}(1 \mathrm{mg} / \mathrm{mL})$, respectively. The modified peptides R23R* and R23L* practically do not give such an antibacterial effect as R23R and R23L (Figure $2 \mathrm{~A})$, that is, for them MIC $\geq 3600-3800 \mu \mathrm{M}(10 \mathrm{mg} / \mathrm{mL})$. At the same time, it should be borne in mind that the data were obtained for the P. aeruginosa strain PA103.

Interestingly, slightly different results on the antimicrobial properties of the peptides were found against the P. aeruginosa strain ATCC 28753 (Table 3).

Inhibition of the P. aeruginosa strain ATCC 28753 cell growth was detected only for R23L at a concentration of $300 \mu \mathrm{M}$ (Table 3). The modified peptides have practically no antibacterial effect, for them the MIC > $300 \mu \mathrm{M}$. It should be noted that the differences in the antimicrobial effects of the R23R peptide in Figure 2 and in Table 3 are likely related to the different survival rates of strains PA103 and ATCC 28753 during co-incubation with this peptide.

In addition, the R23R, R23L, R23R*, and R23L* peptides were also tested on the P. aeruginosa strain ATCC 9027 (Table 4). 
A

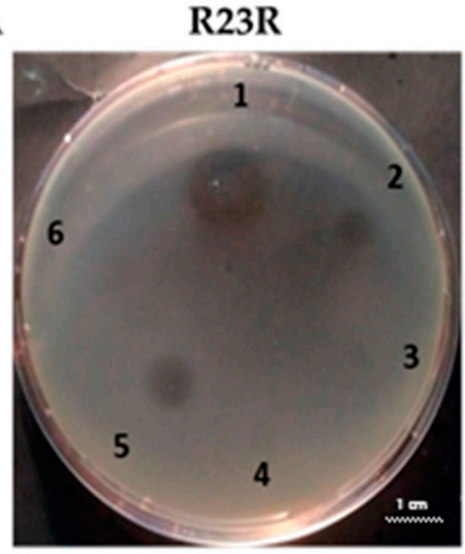

B



R23L



R23L*

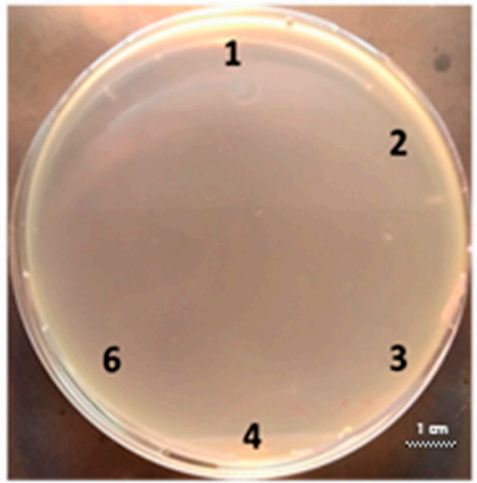

Gentamicin sulfate

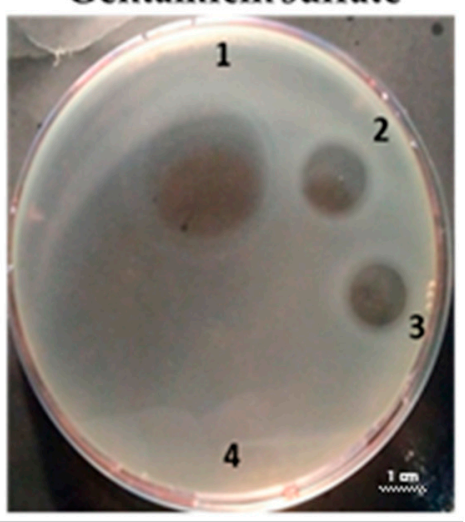

Gentamicin sulfate



Figure 2. Inhibition zone assay after $24 \mathrm{~h}$ of co-incubation peptides R23R, R23L (A) and modified peptides R23R*, R23L* (B) with the cells P. aeruginosa (strain PA103). The test for the antibacterial effect of peptides was carried out according to the following scheme: 1-peptide 3600-3800 $\mu \mathrm{M}$ (gentamicin sulfate 17,000 $\mu \mathrm{M}$ ), 2-peptide 360-380 $\mu \mathrm{M}$ (gentamicin sulfate $1700 \mu \mathrm{M}$ ), 3-peptide 36-38 $\mu \mathrm{M}$ (gentamicin $170 \mu \mathrm{M}$ ), 4-peptide 3.6-3.8 $\mu \mathrm{M}$ (gentamicin sulfate $17 \mu \mathrm{M}$ ), 5-DMSO 100\% (volume/volume), 6-DMSO 20\% (volume/volume). The scale bar is $1 \mathrm{~cm}$.

Table 3. Results of testing the antimicrobial properties of the R23R, R23L, R23R*, and R23L* peptides with the P. aeruginosa (strain ATCC 28753) cells. The scale bar is $1 \mathrm{~cm}$.

\begin{tabular}{|c|c|}
\hline Photo of Results & Scheme \\
\hline $\begin{array}{l}6 \\
4\end{array}$ & $\begin{array}{c}\text { Test of peptide R23R } \\
\text { 1-R23R, } 300 \mu \mathrm{M} \\
\text { 2-R23R, } 250 \mu \mathrm{M} \\
\text { 3-R23R, } 200 \mu \mathrm{M} \\
\text { 4-R23R, } 150 \mu \mathrm{M} \\
\text { 5-DMSO, 2\% (volume/volume) } \\
\text { 6-Gentamicin sulfate, } 1700 \mu \mathrm{M}\end{array}$ \\
\hline 6 & $\begin{array}{c}\text { Test of peptide R23L } \\
\text { 1-R23L, } 300 \mu \mathrm{M} \\
\text { 2-R23L, } 150 \mu \mathrm{M} \\
\text { 3-R23L, } 75 \mu \mathrm{M} \\
\text { 4-R23L, 37.5 } \mu \mathrm{M} \\
\text { 5-DMSO, 2\% (volume/volume) } \\
\text { 6-Gentamicin sulfate, } 1700 \mu \mathrm{M}\end{array}$ \\
\hline
\end{tabular}


Table 3. Cont.

\begin{tabular}{|c|c|}
\hline Photo of Results & Scheme \\
\hline 7 & $\begin{array}{c}\text { Test of peptide R23R* } \\
\text { 1-R23R* } 300 \mu \mathrm{M} \\
\text { 2-R23R* } 150 \mu \mathrm{M} \\
\text { 3-R23R* } 75 \mu \mathrm{M} \\
\text { 4-R23R* } 37.5 \mu \mathrm{M} \\
\text { 5-R23R* } 18.8 \mu \mathrm{M} \\
\text { 6-DMSO, } \% \text { (volume/volume) } \\
\text { 7-Gentamicin sulfate, } 1700 \mu \mathrm{M}\end{array}$ \\
\hline 7 &  \\
\hline
\end{tabular}

Table 4. Results of testing the antimicrobial properties of the R23R, R23L, R23R*, and R23L* peptides with the P. aeruginosa (strain ATCC 9027) cells. The scale bar is $1 \mathrm{~cm}$.




Table 4. Cont.

\begin{tabular}{cc}
\hline Photo of Results & Scheme \\
\hline & Test of peptide $23 R^{*}$ \\
$1-\mathrm{R} 23 \mathrm{R}^{*}, 3750 \mu \mathrm{M}$ \\
$2-\mathrm{R} 23 \mathrm{R}^{*}, 375 \mu \mathrm{M}$ \\
$3-\mathrm{R} 23 \mathrm{R}^{*}, 37.5 \mu \mathrm{M}$ \\
$4-\mathrm{R} 23 \mathrm{R}^{*}, 3.75 \mu \mathrm{M}$ \\
\\
\end{tabular}

Comparing the sizes of the zones of inhibition of cell growth of the P. aeruginosa strain ATCC 9027, it was found that R23R, R23R*, and R23L* do not exhibit antimicrobial activity, while R23L exhibited activity against this strain at a high concentration of $3750 \mu \mathrm{M}$.

It should be noted that the RKKRRQRRRGG-Sar (R12-Sar) peptide itself did not exhibit antimicrobial activity at the concentrations used (see Tables S1 and S2 and Figure S1).

\subsubsection{Measurement of the Antibacterial Activity of Peptides by Microdilution Technique}

From the point of view of testing the antimicrobial properties of peptides, the growth conditions of $P$. aeruginosa cells in a liquid medium may be more interesting (since they are close to in vivo conditions) compared to growth on a solid medium. In this regard, the antimicrobial effects of peptides were tested on P. aeruginosa strains PA103 and ATCC 28753 (Figures 3 and 4, respectively) by microdilution technique.

As seen in Figure 3, the peptides showed no significant antimicrobial activity compared to gentamicin sulfate after $24 \mathrm{~h}$ of incubation with the P. aeruginosa strain PA103 cells grown in a liquid medium. In order to take into account the antimicrobial effects dependent on a particular strain, we tested the same peptides R23R* and R23L* on various P. aeruginosa strains PA103 and ATCC 28753 (Figure 4).

The $\mathrm{R} 23 \mathrm{~L}^{*}$ peptide is able to completely inhibits the growth of bacteria $P$. aeruginosa strain ATCC 28753 at concentrations of $6 \mu \mathrm{M}$, but not of the growth cells PA103 strain (Figure 4B).

\subsection{Toxicity of $R 23 R$ and $R 23 L$}

Figure 5 shows the results of an in vitro toxicity test of the R23R and R23L peptides obtained to determine the viability of human fibroblasts (Figure 5A) and breast tumor cell lines (Figure 5B) after incubation with the peptides for $24 \mathrm{~h}$. 


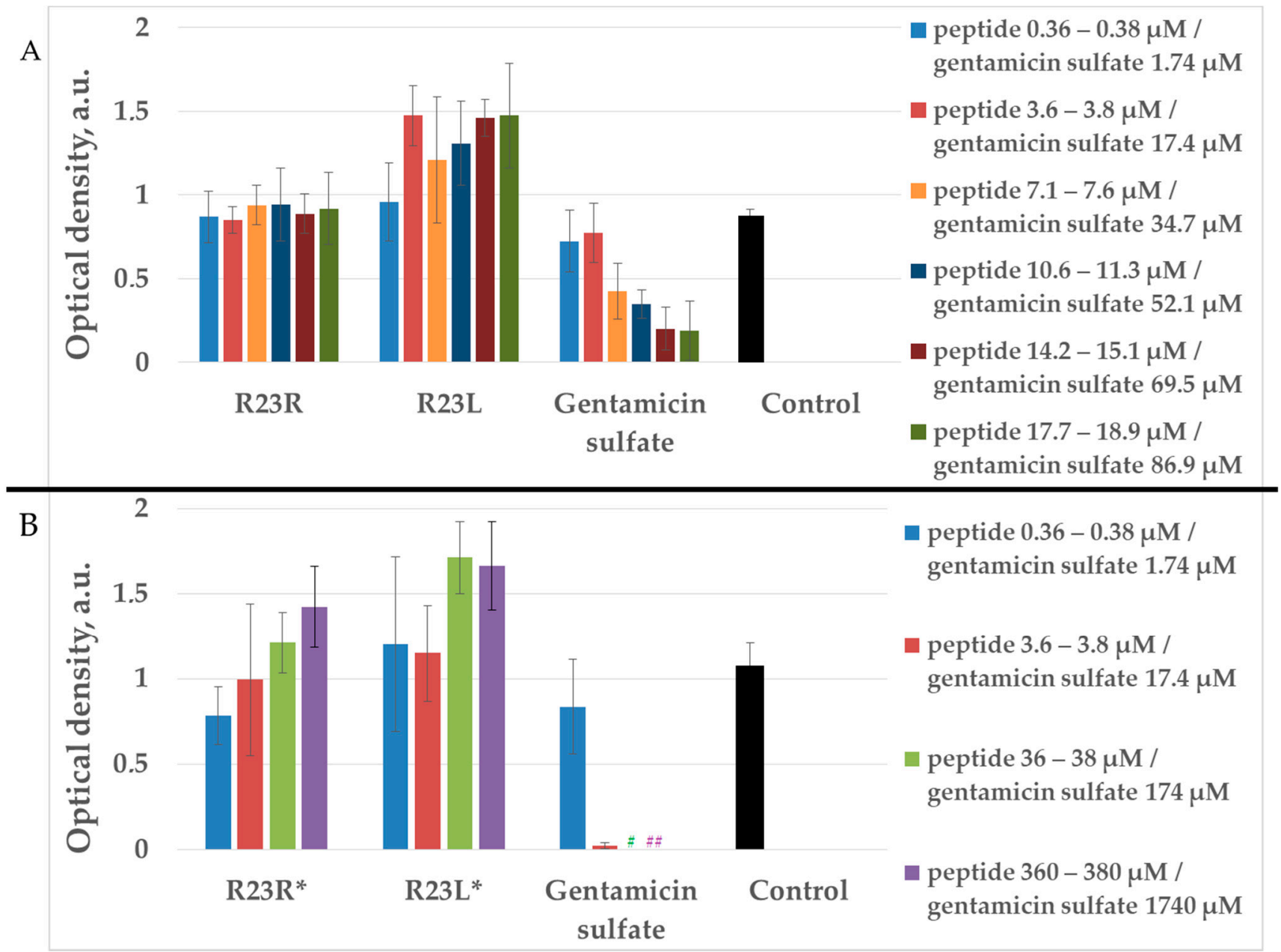

Figure 3. Antibacterial activity of R23R, R23L (A) and modified peptides R23R*, R23L* (B) after 24 h of co-incubation the peptides with the P. aeruginosa (strain PA103) cells. Various concentrations of gentamicin sulfate were used as positive control for the antimicrobial effect. Control is LB medium containing cell culture in $2 \%$ (volume/volume) DMSO without peptide and gentamicin sulfate. Error bars show standard errors. \# Optical density is equal to zero for $174 \mu \mathrm{M}$ concentration of gentamicin sulfate. ${ }^{\# \#}$ Optical density is equal to zero for $1740 \mu \mathrm{M}$ concentration of gentamicin sulfate.

To analyze the cytotoxic effect of peptides, cells after incubation with maximum peptide concentrations $(8 \mu \mathrm{M})$ were stained with calcein-AM (stains living cells) and propidium iodide (stains dead cells). It was shown that all BT474 cells as well as fibroblasts remained alive after $24 \mathrm{~h}$ of incubation with the R23R and R23L peptides. The results of this work show that the studied peptides do not alter the viability of both BT474 human breast duct carcinoma cells and human fibroblasts at maximum concentrations $(8 \mu \mathrm{M})$. The absence of the cytotoxic effect of the studied peptides was shown.

\subsection{Amyloidogenic Properties of Synthesized Peptides}

It is known that thioflavin T (ThT) has the ability to bind to amyloids and amyloid-like fibrils. This process is recorded by a multiple increase in the ThT fluorescence intensity at a wavelength of $\sim 485 \mathrm{~nm}$. ThT fluorescence spectra were obtained after $24 \mathrm{~h}$ of incubation at $37^{\circ} \mathrm{C}$ of the dye with different concentrations of the R23R, R23L, R23R*, and R23L* peptides (Figure 6). 


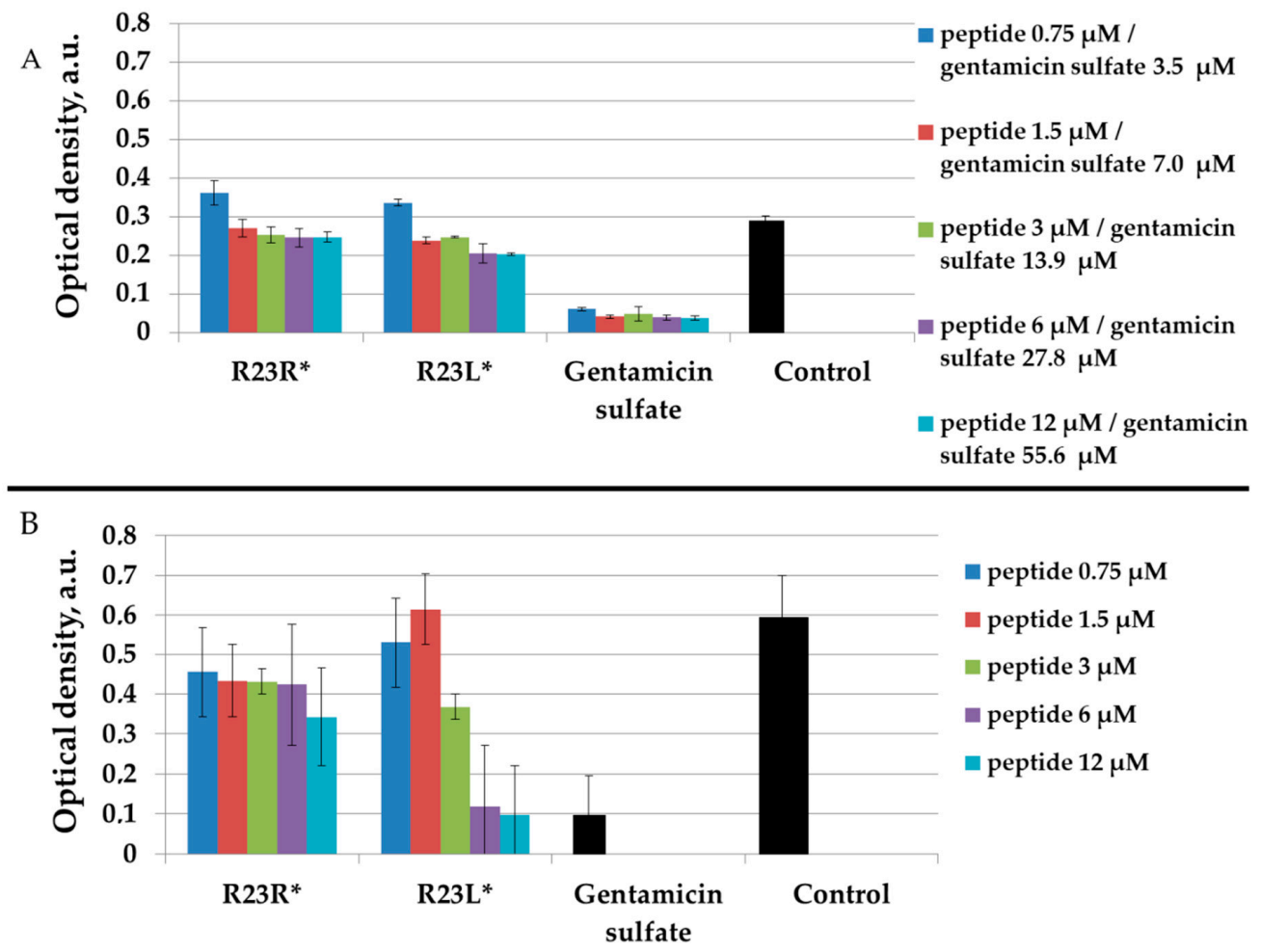

Figure 4. Inhibitory activity of R23R* and R23L* during $16 \mathrm{~h}$ of co-incubation the peptides with the cells P. aeruginosa PA103 (A) and ATCC 28753 (B). Different concentrations (A) and only $1700 \mu \mathrm{M}$ (B) of gentamicin sulfate were used as positive control of antimicrobial effect. The tested bacteria strain without the addition of peptide were used as negative control.



C



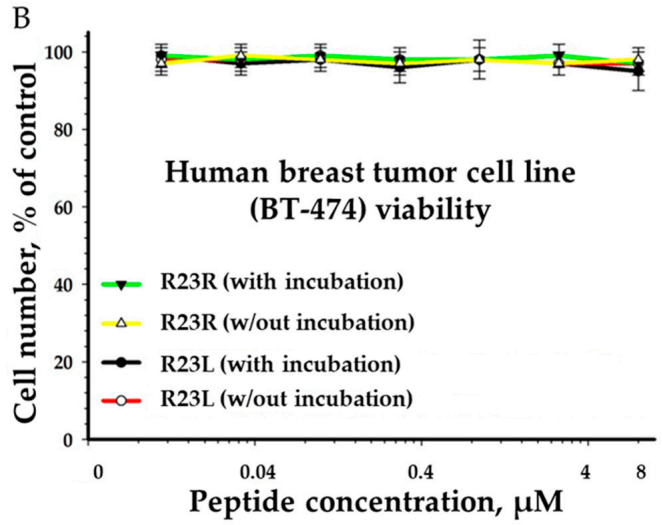

$\mathrm{D}$

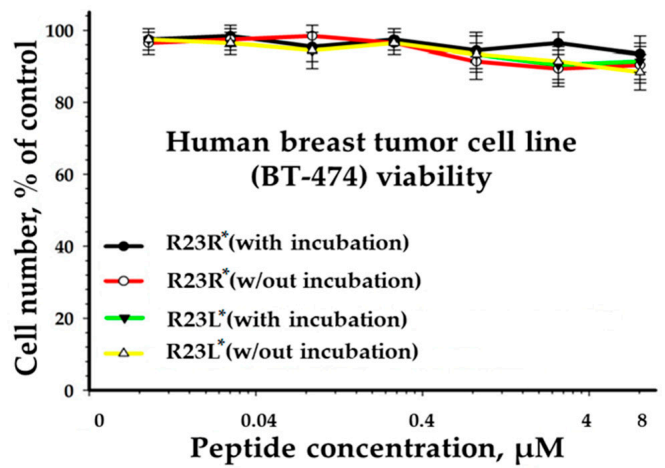

Figure 5. Effects of peptide treatment on survival the human fibroblasts (A,C) and breast tumor cell line BT-474 (B,D). Error bars show standard errors. 



Figure 6. Spectra of fluorescence intensity of free thioflavin T (ThT) and in solution with individual peptides R23R (A), R23L (B), R23R* (C), and R23L* (D) under conditions of $50 \mathrm{mM}$ TrisHCl, $150 \mathrm{mM} \mathrm{NaCl}, \mathrm{pH} 7.5,20 \%$ (volume/volume) $\mathrm{DMSO}$ after $24 \mathrm{~h}$ at $37^{\circ} \mathrm{C}$. Error bars with standard deviations for the mean values of the measured fluorescence intensity are shown.

The effect of a multiple increase in the ThT fluorescence intensity after $24 \mathrm{~h}$ of incubation was obtained for the R23R $(3600 \mu \mathrm{M})$, R23L $(3800$ and $380 \mu \mathrm{M}), \mathrm{R}^{23 \mathrm{~L}^{*}}(3800,380$, and $38 \mu \mathrm{M})$ peptides. This effect was absent for the R23R* peptide at any tested concentration $(\leq 3600 \mu \mathrm{M})$. Moreover, none of the peptides showed an increase in the relative intensity of ThT fluorescence at concentrations of 3.6-3.8 $\mu \mathrm{M}$. In general, it can be concluded that the $\mathrm{R} 23 \mathrm{~L}$ and $\mathrm{R} 23 \mathrm{~L}^{*}$ peptides had the greatest propensity to bind ThT.

\section{Discussions}

AMPs are usually characterized by a stable secondary structure, in particular, the presence of $\beta$-sheets and $\alpha$-helices [68]. A decrease in the ordering of AMPs, in particular, caused by the replacement of amino acid residues with sarcosine, can lead to a decrease in the antimicrobial properties of modified peptides [64].

For the R23R, R23L, R23R*, and R23L* peptides, the secondary structure and physicochemical properties related to the potency and selectivity of AMPs were predicted (Table 1). According to the predictions of the JPred4 [65] and PredictProtein [66] programs, the synthesized R23R, R23L, R23R*, and R23L* peptides contain both disordered and ordered regions of the secondary structure. Thus, according to the JPred 4 program, $\beta$-structure is predicted at the C-terminus of the R23R and R23L peptides. The replacement of glycine 12 with sarcosine leads to a contraction of the ordered region at the C-terminus of the R23R* peptide and but has no effect for the R23L* peptide.

Interestingly, according to the PredictProtein program, the replacement of glycine 12 with sarcosine in the central region of the R23R and R23L peptides leads to a contraction of the $\beta$-strand at the C-terminus of the modified R23R* and R23L* peptides. At the same time, the amino acid modification practically does not affect the results of helix prediction at the $\mathrm{N}$-terminus of peptides, in the region corresponding to the CPP (Tat fragment). Thus, according to the predictions of the JPred 4 and PredictProtein programs, the replacement of the glycine residue with sarcosine in the linker region of the peptide ("CPP" +"linker 
GGGG"+"predicted amyloidogenic-fragment") affects the results of predicting the secondary structure of the peptide in its amyloidogenic region. In turn, a change in the secondary structure, can lead to a change in the antimicrobial action of peptides [69].

It is known that peptides with high hydrophobicity $\left(\mathrm{H}_{n}\right)$ integrate better into the phospholipid bilayer of a bacterial cell, and a high hydrophobic moment $\left(\mu \mathrm{H}_{n}\right)$ allows peptides to form a water channel, which, in turn, can enhance their antimicrobial effect. $\mathrm{H}_{n}$ and $\mu \mathrm{H}_{\mathrm{n}}$ are closely related to the general amphiphilicity, the ability of peptides to aggregate in solution, and also to interact with cell membranes [70,71]. However, an excessively high value of $\mathrm{H}_{\mathrm{n}}$ is already associated with disordered aggregation of peptides, as well as with an increase in their toxicity towards eukaryotic cells [72,73]. It was shown that a decrease in $\mathrm{H}_{n}$ and $\mu \mathrm{H}_{n}$ increases antimicrobial selectivity, but also decreases the overall antimicrobial activity of peptides [74]. It can be expected that the modified R23R* and R23L* peptides, in comparison with R23R and R23L, will exhibit a lower antimicrobial effect, but a higher selectivity with respect to different phospholipid composition of different bacteria (species and strains). The charge of peptide (Z) is important both for interaction with the bacterial membrane and for loading the peptide into the carrier [75]. For interaction with a negatively charged bacterial membrane, it is preferable that the antimicrobial peptide has a sufficiently high positive charge $(\mathrm{Z}=+5-+12)$. The isoelectric point $\left(\mathrm{I}_{0}\right)$ of the peptide should have a value that is very different from the $\mathrm{pH}$ value of the buffer solution $\left(\mathrm{I}_{0}>9\right)$, in which the antimicrobial properties of the peptides are tested (as a rule, the $\mathrm{pH}$ value is $7-8$, close to the physiological conditions of a bacterial cell). As shown in Table 1, modification glycine 12 does not appear to affect the $\mathrm{Z}$ and $\mathrm{I}_{0}$ values for the R23R, R23L, R23R*, and R23L* peptides. At the same time, the peptides have $\mathrm{Z}$ ( +9 for R23R and +7 for R23L) and $\mathrm{I}_{0}$ (12.51 for R23R and 12.41 for R23L), which contribute to the manifestation of antimicrobial effects [32].

Data on the secondary structure and physicochemical properties of peptides, in turn, can be used to predict their antimicrobial properties using existing bioinformatics tools [76,77]. In Table 2 the antimicrobial activity was assessed using four algorithms from the CAMPR3 online server: random forests (RF), support vector machine (SVM), artificial neural network (ANN), and discriminant analysis (DA). The prediction results are highly dependent on the algorithm used. Thus, DA predicted antimicrobial properties for all four peptides R23R, R23L, R23R*, and R23L*. At the same time, the SVM algorithm did not find any antimicrobial peptides among the synthesized peptides. The AmpGram tool predicted R23R and R23R* would be more suitable as antimicrobial peptides than R23L and R23L*. At the same time, AMP Scanner favored R23L and R23L* as antimicrobials over R23R and R23R*, which had no predictable antimicrobial properties. According to the predictions of the online servers CAMPR3, AmpGram, AMP Scanner, replacing glycine 12 with sarcosine did not significantly change the predictions of antimicrobial properties of the modified peptides.

Testing of the peptides on P. aeruginosa strains revealed antimicrobial activity that is specific for the strain and growth condition. R23R and R23L were active against both strains PA103, and ATCC 28753 with the MIC of about $300 \mu \mathrm{M}$, when tested on agar medium (Figure 2 and Table 3 respectively). For comparison, the MIC of the antibiotic gentamicin sulfate was $170 \mu \mathrm{M}$. The modified peptides R23R* and R23L* had no bactericidal effect against bacteria grown on agar. P. aeruginosa strain ATCC 9027 used in the study was the least sensitive to the action of the synthesized peptides.

P. aeruginosa strains behaved differently when growing in a liquid medium (Figures 3 and 4). PA103 was generally resistant to all peptides. In contrast, the R23L* peptide inhibited the growth of ATCC 28753 cells at low concentrations of 6 and $12 \mu \mathrm{M}$. These effects, depending on the strain and cultivation condition, can be due to strain-specific differences and the well-known morphologic plasticity of $P$. aeruginos $a$, which provides the appearance of morphotypes that differ in sensitivity to antibiotics, the presence or absence of exoenzymes, pigmentation, and antigenicity even within the same culture [78]. Experiments on spontaneous aggregation demonstrated that the ability of cells to form unbound aggregates strongly depends on the bacterial strain [79]. 
At the same time the antibacterial properties of the R23L and R23L* peptides are higher than those of R23R and R23R*. This effect can be associated with different cytotoxicity of peptides towards $P$. aeruginosa cells based on the different amyloidogenicity of the sequence of the R23R, R23L, R23R*, and R23L* peptides. All peptides were developed for targeted coaggregation with the S1 protein from P. aeruginosa; therefore, their antimicrobial (cytotoxic) action should be specific for these bacterial cells and not on eukaryotic cells. It is known that antimicrobial peptides can exhibit differential cytotoxicity to various types of mammalian cell lines [80]. We tested the differences in the cytotoxicity of peptides R23R, $\mathrm{R}^{2} 3 \mathrm{R}^{*}, \mathrm{R} 23 \mathrm{~L}$, and R23L* in relation to human fibroblast and carcinoma cells (Figure 5). According to the results of such tests, it was revealed that the peptides did not have a toxic effect on eukaryotic cells at the tested concentrations $(\leq 8 \mu \mathrm{M})$.

As discussed in the Introduction, the R23L and R23L peptides were developed based on the amyloidogenic sequence ITDFGIFIGL, which forms amyloid-like fibrils, while $R 23 R$ and $R 23 R^{*}$ did contain amyloidogenic sequence, however they failed to identify amyloidogenic properties through their conducted studies [51]. Thus, as can be seen from the results of measuring ThT fluorescence (Figure 6), the R23L and R23L* peptides are more prone to amyloidogenesis than R23R and R23R*. In an earlier study [26], in which the amyloidogenic and antimicrobial effects of peptides based of the S1 protein from the model organism T. thermophilus were assessed from two hybrid peptides (R23I and R23T), R23I showed a higher antimicrobial effect. Interestingly, R23I in comparison with R23T, as well as R23L in comparison with R23R, was more amyloidogenic. Increasing the length of peptides and proteins can reduce their amyloidogenicity (the number of amino acid residues predicted to be amyloidogenic), as was discussed in [81]. At the same time, it was shown that whole proteins with a molecular weight of more than $60 \mathrm{kDa}$ can exhibit an antimicrobial effect [82]. We have previously shown that peptide modification decreases the ability of peptides to form fibrils, but increases the ability of peptides to suppress the growth of T. thermophilus cell culture [26]. Previously, similar results were reported, showing that the polymorphism of fibrils of amyloidogenic peptides [83] can have a strong influence on its antimicrobial effects and variable cytotoxicity [84].

It is noteworthy that the synthesized peptides did not show the same effectiveness against various strains of $P$. aeruginosa. In this regard, it is necessary to develop new modified hybrid AMPs in order to improve their antimicrobial properties, in particular, to increase the half-life in the bacterial cell, potency in coping with persister cells, as well as to prevent biofilm formation. Therefore, of great interest is the work [85], in which the properties of cathelicidin-BF15 were significantly improved by changing the composition of the original amino acid sequence and cyclization of the peptide. The modified ZY4 peptide proved to be an ideal candidate not only against different strains of P. aeruginosa, but also against different species of pathogens. Of course, it is necessary to compare the antimicrobial effect of different peptides on the same strain and under the same conditions. In our case, the R23L* peptide showed a significant antimicrobial effect against ATCC 28753 strain at a concentration of 6-12 $\mu \mathrm{M}$ comparable with gentamicin sulfate (Figure 4 ) and did not show a significant antimicrobial effect against the PA103 strain at a concentration of $380 \mu \mathrm{M}$ (Figure 3). Moreover, for the known antimicrobial peptide Mel4 [86], differences in effective concentrations were shown when tested on various strains of $P$. aeruginosa. However, the differences in MIC are not as large as for our R23L* peptide. At the same time, it should be noted that Mel4 is very active against $P$. aeruginosa due to the destruction of cell membranes and lysis of bacteria [87]. In turn, the main mechanism of action for R23L* is assumed to be different, associated with directed coaggregation with the ribosomal S1 protein. R23L* is interesting from the point of view of the use of antimicrobial peptides with different mechanisms of action. It can be expected that bacteria will develop resistance to the $\mathrm{R} 23 \mathrm{~L}^{*}$ peptide for a longer time. In the future, it is planned to determine the effect of amino acid modification (G12-> Sar12) in the non-amyloidogenic region of peptides on the change in the proteomic composition of various P. aeruginosa strains treated with the R23R, R23L, R23R*, and R23L* peptides. At the same time, the antimicrobial effect of 
peptides R23L and R23L* is comparable with the commercial antibiotic gentamicin sulfate. The antimicrobial effect can be enhanced by increasing the overall amyloidogenicity of new peptides synthesized based on the S1 protein sequence from $P$. aeruginosa and by considering other cell penetrating peptides.

\section{Materials and Methods}

4.1. Synthesis and Characterization of Peptides

4.1.1. Peptide Synthesis

Peptides RKKRRQRRRGGGGLHITDMAWKR (R23R, 2820.3 Da) and RKKRRQRRRGGGGITDFGIFIGL (R23L, 2645.1 Da) were commercial products (IQ Chemical LLC, S. Petersburg, Russia). Peptides RKKRRQRRRGG-Sar-GLHITD-Nle-AWKR (R23R* 2815.3 Da), RKKRRQRRRGG-Sar-GITDFGIFIGL (R23L*, 2658.1 Da), and RKKRRQRRRGG-Sar (R12Sar, 1523.8 Da) were synthesized in-house using routine techniques of Fmoc/ ${ }^{\mathrm{t}} \mathrm{Bu}$ SPPS methodology [61]. Semipreparative RP-HPLC purification was carried out in isocratic mode (mobil phase " $\mathrm{A}$ " $0.1 \%$ TFA in water, mobil phase " $\mathrm{B}$ " acetonitrile (no additives), $22 \%$ "B" for R23R* and 32\% B for R23L*) on Luna C18 $250 \times 21.5 \mathrm{~mm}(10 \mu \mathrm{m})$ column (Phenomenex, Torrance, CA, USA) using Gilson instrument equipped with model 305/302 binary pump, model 803 manometric module and model 811 dynamic mixer at flow rate $10 \mathrm{~mL} / \mathrm{min}$ (Gilson, Middleton, WI, USA). The fractions collected were analyzed using RP-HPLC on Luna 5 um C18 (2) $100 \AA 250 \times 4.6$ column (Phenomenex, Torrance, CA, USA) using Waters instrument equipped with Waters 2487 Dual Absorbance Detector and Waters 1525 Binary HPLC Pump (Waters, Milford, MA, USA). The appropriate fractions were lyophilized and the peptide identity was confirmed using an Orbitrap Elite mass spectrometer (Thermo Scientific, Dreieich, Germany). The estimated peptide molecular weight coincided with the calculated one.

\subsubsection{Bioinformatic Analysis of Peptides}

Amyloidogenic regions of protein bPaS1 from P. aeruginosa with a length of at least five amino acid residues were determined using four programs-AGGRESCAN, FoldAmyloid, Pasta 2.0, and Waltz [51]. Predicted amyloidogenic regions were checked in vitro by their ability to form amyloid-like aggregates and two sequences (LHITDMAWKR, ITDFGIFIGL) were used as "amyloidogenic" parts for the R23R, R23L, R23R*, and R23L* peptides.

Default software settings by JPred4 [65], PredictProtein [66], DBAASP v3.0 [67], CAMPR3 [9], AmpGram [7], and AMP Scanner [8] were used for the prediction of secondary structure, physicochemical and antimicrobial properties of R23R, R23L, R23R*, and R23L*.

The JPRED4 program makes secondary structure prediction of protein sequences by the JNET algorithm (jnetpred), http:/ / www.jalview.org/help/html/webServices/jnet. html (accessed on 2 August 2021) [65]. PredictProtein provides secondary structure prediction (helix, strand, and other) for each amino-acid residue in the query by according the RePROF tool, https://predictprotein.org/ (accessed on 2 August 2021) [66,88]. Among the elements of the secondary structure predicted by the JPred 4 and PredictProtein programs, fragments of peptides with a length of at least 5 amino acid residues were selected (just as the amyloidogenic regions were previously selected by length).

The "Moon and Fleming" (MF) hydrophobicity scale of the "Property Calculation" tool of the Database of Antimicrobial Activity and Structure of Peptides (DBAASP v3.0) was used to predict the physicochemical characteristics of peptides, https://dbaasp.org/ property-calculation (accessed on 2 August 2021) [67,89]. All algorithms of the "Predict Antimicrobial Peptides" tool of Collection of Anti-Microbial Peptides (database CAMPR3) were used to predict AMP probability for the R23R, R23L, R23R*, and R23L* peptides, http:/ / www.camp.bicnirrh.res.in/predict/ (accessed on 2 August 2021) [9]. The effect of replacement one residue in the peptides (glycine 12 with proline or alanine residues as similar to sarcosine in structure and properties) was studied using four algorithms, namely random forest (RF), support vector machine (SVM), artificial neural network (ANN), and discriminant analysis (DA) [90]. 
AmpGram uses the RF algorithm based on amino acid motifs (n-grams) encoded peptides for calculation of AMP probability, http:/ / biongram.biotech.uni.wroc.pl/AmpGram/ (accessed on 2 August 2021) [7]. AMP Scanner vr.2 proposes a deep neural network (DNN) classifier for predicting AMP from sequence alone a peptide/protein, https:/ /www.dveltri. com/ascan/v2/ascan.html (accessed on 2 August 2021) [8].

A peptide is classified as AMP if the probability is equal to or greater than 0.5 , and the peptide is classified as non-AMP if the probability is less than 0.5 based on prediction results using the CAMPR3, AmpGram, AMP Scanner tools.

\subsection{Antimicrobial Activity of Peptides}

4.2.1. Determination of the Antibacterial Properties of Peptides on Agar

The R23R, R23L, R23R*, R23L* peptides and an antibiotic (gentamicin sulfate) were dissolved in $100 \%$ DMSO and solutions were prepared to test their activity.

The culture of the studied bacteria (P. aeruginosa strain PA103) was diluted 10 times in Luria-Bertani (LB) medium with non-solidified $0.75 \%$ agar $(\mathrm{w} / \mathrm{w})$ on sterile Petri dishes. Drops of the sample (a solution of peptide or gentamicin sulfate with a final concentration of DMSO) 20\% (volume/volume) at concentrations: 1-peptide 3600-3800 $\mu \mathrm{M}$ (gentamicin sulfate 17,000 $\mu \mathrm{M}$ ), 2-peptide 360-380 $\mu \mathrm{M}$ (gentamicin sulfate $1700 \mu \mathrm{M}$ ), 3-peptide 36-38 $\mu \mathrm{M}$ (gentamicin sulfate $170 \mu \mathrm{M}$ ), 4-peptide 3.6-3.8 $\mu \mathrm{M}$ (gentamicin sulfate $17 \mu \mathrm{M}$ ), are applied to the surface of agar plates, and after $24 \mathrm{~h}$ incubation, the result is assessed by the presence of zones of inhibition.

The P. aeruginosa strain ATCC 28753 was inoculated with a wire loop in $5 \mathrm{~mL}$ of LB medium and was incubated at $37^{\circ} \mathrm{C}$. After $12 \mathrm{~h}$, plastic Petri dishes were poured with LB medium (about $5 \mathrm{~mL}$ ) with $0.75 \%$ agar. Before pouring, $50 \mu \mathrm{L}$ of an overnight culture of the test bacteria was added to each dish. The R23R, R23L, R23R*, and R23L* peptides were finally dissolved in $2 \%$ (volume/volume) DMSO and was tested with different concentrations with gentamicin sulfate as control of antimicrobial effect. The medium was dried and $10 \mu \mathrm{L}$ of the prepared peptides were applied to it in accordance with the labeling. Then the dishes were placed in a thermostat and incubated for $12 \mathrm{~h}$ at a temperature of $37^{\circ} \mathrm{C}$. Antimicrobial activity was recorded by the presence of transparent zones of no growth around drops with peptide.

Studies with the P. aeruginosa strain ATCC 9027 were carried out similarly to the P. aeruginosa strain ATCC 28753. The exception was the amount of LB medium. Sterile plastic Petri dishes were filled with LB medium (about $25 \mathrm{~mL}$ ) with $0.75 \%$ agar and $250 \mu \mathrm{L}$ of an overnight culture of the test bacteria was added to each dish.

\subsubsection{Determination of MIC by Broth Dilution Method}

The R23R, R23L, R23R*, R23L* peptides and an antibiotic (gentamicin sulfate) were dissolved in $100 \%$ DMSO and solutions were prepared with a final DMSO concentration of $2 \%$ (volume/volume) to test their activity.

Stationary culture of P. aeruginosa strain PA103 was diluted 100 times in fresh LB medium with peptides R23R and R23L or gentamicin sulfate (positive control) at various concentrations. After $24 \mathrm{~h}$ at $37^{\circ} \mathrm{C}$ co-incubation bacterial cells with peptides, the optical densities of the cultures were measured at a wavelength of $600 \mathrm{~nm}$ in a plate reader iMac (BioRad Laboratories, Hercules, CA, USA). Each test was carryout in three replicates.

In the next experiment to prepare a stationary culture of P. aeruginosa, strain PA103, a colony was inoculated from a Petri dish in $1.5 \mathrm{~mL}$ of liquid LB medium and set to grow for $24 \mathrm{~h}$ at $37^{\circ} \mathrm{C}$ and with stirring at $180 \mathrm{rpm}$. In the experiment, we used a culture with an initial concentration of $\approx 10^{6}-10^{7} \mathrm{CFU} / \mathrm{mL}(10 \mu \mathrm{L})$, sterile LB medium $(80 \mu \mathrm{L})$, peptides $\mathrm{R}^{2} 3 \mathrm{R}^{*}$ and $\mathrm{R} 23 \mathrm{~L}^{*}$ diluted in $20 \%$ (volume/volume) DMSO or the antibiotic gentamicin sulfate as a positive control $(10 \mu \mathrm{L})$. Final concentrations of peptides $12 \mu \mathrm{M}, 6 \mu \mathrm{M}, 3 \mu \mathrm{M}$, $1.5 \mu \mathrm{M}$, and $0.75 \mu \mathrm{M}$ and gentamicin sulfate are $55.6 \mu \mathrm{M}, 27.8 \mu \mathrm{M}, 13.9 \mu \mathrm{M}, 7 \mu \mathrm{M}, 3.5 \mu \mathrm{M}$. As a control, we used: (1) a culture diluted 1000 times with a medium without peptides and antibiotics with the addition of sterile physical. Solution $(10 \mu \mathrm{L}) ;(2)$ culture diluted 
1000 times liquid LB medium with DMSO at a final concentration of $2 \%(10 \mu \mathrm{L})$. The samples were grown for $10 \mathrm{~h}$ at $37^{\circ} \mathrm{C}$ in the wells of flat-bottom sterile 96-well Linbro plastic plates (Flow Laboratories; McLean, VA, USA). Optical density was measured in a plate reader iMac (BioRad Laboratories, Hercules, CA, USA) at a wavelength of $600 \mathrm{~nm}$ every hour from $0 \mathrm{~h}$ to $24 \mathrm{~h}$. Each sample is measured in duplicate.

Determination of the MIC for P. aeruginosa strain ATCC 28753 was performed using Mueller-Hinton Broth (MHB) (Sigma-Aldrich, St. Louis, MO, USA). The composition of the reaction medium: $80 \mu \mathrm{L} \mathrm{MHB;} 10 \mu \mathrm{L}$ bacteria at a concentration of $\approx 10^{6}-10^{7} \mathrm{CFU} / \mathrm{mL}$; peptide (each peptide was dissolved to a final concentration of $12 \mu \mathrm{M}, 6 \mu \mathrm{M}, 3 \mu \mathrm{M}, 1.5 \mu \mathrm{M}$, and $0.75 \mu \mathrm{M}$, respectively). P. aeruginosa cells were incubated with or without a peptide in a 96-well microtiter plate for 16-24 h, data was taken every $30 \mathrm{~min}$. Bacterial growth was assessed by spectrophotometry using a spectrophotometer Multiskan GO (Thermo Scientific, Waltham, MA, USA). The effect of gentamicin sulfate on the cell culture growth served as a positive control. Sterile MHB with $2 \%$ (volume/volume) final concentration of DMSO and the tested bacteria strain without the addition of peptide were used as negative controls.

\subsection{Cytotoxicity Assay}

Cell viability was estimated as described previously by resazurin cell viability assay $[26,91]$. Each assay was done in triplicate. All measurements were carried out on the control samples that were not treated with cytotoxic substances. We used human diploid fibroblasts and human breast duct carcinoma BT474 cells obtained from the American Type Cell Culture Collection (Manassas, Virginia, VA, USA). BT474 cells were cultured in DMEM medium (Sigma-Aldrich, St. Louis, MO, USA) supplemented with 10\% fetal bovine serum (Gibco, Waltham, MA, USA), $40 \mu \mathrm{g} / \mathrm{mL}$ gentamicin sulfate (Sigma-Aldrich, St. Louis, MO, USA), at $37^{\circ} \mathrm{C}$, under conditions of $5 \%$ content $\mathrm{CO}_{2}$ in the air. The analysis of living and dead cells was carried out using BD Accuri C6 flow cytometer (BD Bioscience, San Jose, CA, USA).

\subsection{Thioflavin T Fluorescence Measurement}

Preparations of the R23R, R23L, R23R*, and R23L* peptides in buffer conditions $50 \mathrm{mM}$ TrisHCl, pH 7.5; $150 \mathrm{mM} \mathrm{NaCl}, 20 \%$ (volume/volume) DMSO was incubated with $200 \mu \mathrm{M}$ thioflavin $\mathrm{T}$ (ThT) at $37^{\circ} \mathrm{C}$ with shaking for $24 \mathrm{~h}$ at $450 \mathrm{rpm}$ in a thermostatic mixer Thermomixer comfort (Eppendorf, Hamburg, Germany). The spectra of fluorescence intensity of free ThT and in solution with individual peptides were studied by us using the method of fluorescence spectroscopy as described previously [51].

\subsection{Statistical Analysis}

The obtained results were statistically manipulated with OriginPro (OriginLab Corporation, Northampton, MA, USA) software. Data are presented as the mean \pm standard deviation $(\mathrm{M} \pm \mathrm{SD})$. The experiments were performed in at least two repetitions $(n \geq 2)$. The statistical significance of the difference was determined using the Student's t-test and analysis of variance (ANOVA).

\section{Conclusions}

In this study, we have developed and synthesized antimicrobial peptides R23R, R23L, as well as their analogs R23R*, R23L*. The secondary structure, antimicrobial and amyloidogenic properties of the peptides were predicted and evaluated. The combination of the bioinformatic, microbiological, and physical methods used made it possible to assess the antimicrobial properties of the R23R, R23L, R23R*, and R23L* peptides, as well as the effect on these properties of only one amino acid modification (glycine at 12 position is replaced with sarcosine). The $\mathrm{R} 23 \mathrm{~L}$ and $\mathrm{R} 23 \mathrm{~L}^{*}$ peptides have higher antimicrobial activity than the R23R and R23R* peptides, and the MIC for R23L* was comparable to the antibiotic gentamicin sulfate for the P. aeruginosa strain ATCC 28753. 
Supplementary Materials: Supplementary Materials can be found at https:/ /www.mdpi.com/ article/10.3390/ijms22189776/s1.

Author Contributions: Conceptualization and designed the experiments: S.Y.G., S.V.K., V.N.A., A.S.V., V.V.F., S.A.E., O.V.G.; software: S.Y.G., S.R.K., P.A.D., S.V.K., M.I.K.; formal analysis: S.Y.G., P.A.D., S.V.K., V.N.A., L.G.M., E.Y.G., M.I.K., A.K.S.,M.A.M., S.R.K., R.S.F., A.S.V., V.V.F., S.A.E., O.V.G.; visualization: S.Y.G., S.R.K., P.A.D., S.V.K., M.A.M.; investigation: S.Y.G., P.A.D., S.V.K., V.N.A., L.G.M., E.Y.G., M.I.K., A.K.S., M.A.M., S.R.K., R.S.F., A.S.V., V.V.F., S.A.E., O.V.G.; methodology: S.Y.G., P.A.D., S.V.K., V.N.A., L.G.M., E.Y.G., M.I.K., A.K.S., M.A.M., S.R.K., R.S.F., A.S.V., V.V.F., S.A.E., O.V.G.; resources: S.Y.G., P.A.D., S.V.K., V.N.A., L.G.M., E.Y.G., M.I.K., A.K.S., M.A.M., S.R.K., R.S.F., A.S.V., V.V.F., S.A.E., O.V.G.; writing original draft preparation: S.Y.G., S.A.E., A.S.V., V.V.F., R.S.F., V.N.A., O.V.G.; writing-review \& editing, O.V.G.; supervision, O.V.G.; funding acquisition: O.V.G. All authors have read and agreed to the published version of the manuscript.

Funding: This research was funded by the Russian Science Foundation, grant number 18-14-00321.

Institutional Review Board Statement: Not applicable.

Informed Consent Statement: Not applicable.

Acknowledgments: Mass spectrometry measurements were carried out by facilities of the Center for Collective Employment for Mass Spectrometry of IPR RAS (584307).

Conflicts of Interest: The authors declare no conflict of interest.

$\begin{array}{ll}\text { Abbreviations } \\ \text { AMP } & \text { antimicrobial peptide } \\ \text { ANN } & \text { artificial neural network } \\ \text { CPP } & \text { cell penetrating peptide } \\ \text { DA } & \text { discriminant analysis } \\ \text { DNN } & \text { deep neural network } \\ \text { LB } & \text { Luria-Bertani (medium) } \\ \text { MHB } & \text { Mueller-Hinton broth } \\ \text { MIC } & \text { Minimum inhibitory concentration } \\ \text { OB-fold } & \text { oligonucleotide/oligosaccharide-binding fold } \\ \text { RF } & \text { random forest } \\ \text { SVM } & \text { support vector machine } \\ \text { ThT } & \text { tioflavin T }\end{array}$

\section{References}

1. Teixeira, M.C.; Carbone, C.; Sousa, M.C.; Espina, M.; Garcia, M.L.; Sanchez-Lopez, E.; Souto, E.B. Nanomedicines for the Delivery of Antimicrobial Peptides (AMPs). Nanomaterials 2020, 10, 560. [CrossRef]

2. Honda, M.; Matsumoto, M.; Aizawa, M. Potential Application of Protamine for Antimicrobial Biomaterials in Bone Tissue Engineering. Int. J. Mol. Sci. 2020, 21, 4368. [CrossRef]

3. Moretta, A.; Scieuzo, C.; Petrone, A.M.; Salvia, R.; Manniello, M.D.; Franco, A.; Lucchetti, D.; Vassallo, A.; Vogel, H.; Sgambato, A.; et al. Antimicrobial Peptides: A New Hope in Biomedical and Pharmaceutical Fields. Front. Cell. Infect. Microbiol. 2021, 11, 453. [CrossRef]

4. Dey, S.; Gill, K.; Kumar, S.; Xess, I. Novel synthetic anti-fungal tripeptide effective against Candida krusei. Indian J. Med. Microbiol. 2015, 33, 110. [CrossRef]

5. Ahmed, A.; Siman-Tov, G.; Hall, G.; Bhalla, N.; Narayanan, A. Human Antimicrobial Peptides as Therapeutics for Viral Infections. Viruses 2019, 11, 704. [CrossRef] [PubMed]

6. Dong, N.; Wang, C.; Zhang, T.; Zhang, L.; Xue, C.; Feng, X.; Bi, C.; Shan, A. Bioactivity and Bactericidal Mechanism of Histidine-Rich $\beta$-Hairpin Peptide Against Gram-Negative Bacteria. Int. J. Mol. Sci. 2019, 20, 3954. [CrossRef]

7. Burdukiewicz, M.; Sidorczuk, K.; Rafacz, D.; Pietluch, F.; Chilimoniuk, J.; Rödiger, S.; Gagat, P. Proteomic Screening for Prediction and Design of Antimicrobial Peptides with AmpGram. Int. J. Mol. Sci. 2020, 21, 4310. [CrossRef]

8. Veltri, D.; Kamath, U.; Shehu, A. Deep learning improves antimicrobial peptide recognition. Bioinformatics 2018, 34, $2740-2747$. [CrossRef] [PubMed]

9. Waghu, F.H.; Barai, R.S.; Gurung, P.; Idicula-Thomas, S. CAMPR3: A database on sequences, structures and signatures of antimicrobial peptides. Nucleic Acids Res. 2016, 44, D1094-D1097. [CrossRef] 
10. Mulcahy, L.R.; Isabella, V.M.; Lewis, K. Pseudomonas aeruginosa Biofilms in Disease. Microb. Ecol. 2014, 68, 1-12. [CrossRef] [PubMed]

11. Rodrigo-Troyano, A.; Melo, V.; Marcos, P.J.; Laserna, E.; Peiro, M.; Suarez-Cuartin, G.; Perea, L.; Feliu, A.; Plaza, V.; Faverio, P.; et al. Pseudomonas aeruginosa in Chronic Obstructive Pulmonary Disease Patients with Frequent Hospitalized Exacerbations: A Prospective Multicentre Study. Respiration 2018, 96, 417-424. [CrossRef] [PubMed]

12. Coleman, S.R.; Blimkie, T.; Falsafi, R.; Hancock, R.E.W. Multidrug Adaptive Resistance of Pseudomonas aeruginosa Swarming Cells. Antimicrob. Agents Chemother. 2019, 64, e01999-19. [CrossRef] [PubMed]

13. Khan, M.; Stapleton, F.; Summers, S.; Rice, S.A.; Willcox, M.D.P. Antibiotic Resistance Characteristics of Pseudomonas aeruginosa Isolated from Keratitis in Australia and India. Antibiotics 2020, 9, 600. [CrossRef] [PubMed]

14. Shemyakin, I.G.; Firstova, V.V.; Fursova, N.K.; Abaev, I.V.; Filippovich, S.Y.; Ignatov, S.G.; Dyatlov, I.A. Next-Generation Antibiotics, Bacteriophage Endolysins, and Nanomaterials for Combating Pathogens. Biochemistry 2020, 85, 1374-1388. [CrossRef]

15. Lam, A.K.; Panlilio, H.; Pusavat, J.; Wouters, C.L.; Moen, E.L.; Rice, C.V. Overcoming Multidrug Resistance and Biofilms of Pseudomonas aeruginosa with a Single Dual-Function Potentiator of $\beta$-Lactams. ACS Infect. Dis. 2020, 6, 1085-1097. [CrossRef]

16. Bhagirath, A.Y.; Li, Y.; Patidar, R.; Yerex, K.; Ma, X.; Kumar, A.; Duan, K. Two Component Regulatory Systems and Antibiotic Resistance in Gram-Negative Pathogens. Int. J. Mol. Sci. 2019, 20, 1781. [CrossRef] [PubMed]

17. Pang, Z.; Raudonis, R.; Glick, B.R.; Lin, T.-J.; Cheng, Z. Antibiotic resistance in Pseudomonas aeruginosa: Mechanisms and alternative therapeutic strategies. Biotechnol. Adv. 2019, 37, 177-192. [CrossRef]

18. Bukhari, S.I.; Aleanizy, F.S. Association of OprF mutant and disturbance of biofilm and pyocyanin virulence in pseudomonas aeruginosa. Saudi Pharm. J. 2020, 28, 196-200. [CrossRef]

19. Mishra, B.; Wang, G. Individual and Combined Effects of Engineered Peptides and Antibiotics on Pseudomonas aeruginosa Biofilms. Pharmaceuticals 2017, 10, 58. [CrossRef]

20. Gupta, V.; Datta, P. Next-generation strategy for treating drug resistant bacteria: Antibiotic hybrids. Indian J. Med. Res. 2019, 149, 97. [CrossRef]

21. Sarno, R.; Ha, H.; Weinsetel, N.; Tolmasky, M.E. Inhibition of Aminoglycoside 6'-N-Acetyltransferase Type Ib-Mediated Amikacin Resistance by Antisense Oligodeoxynucleotides. Antimicrob. Agents Chemother. 2003, 47, 3296-3304. [CrossRef] [PubMed]

22. Livermore, D.M. Multiple Mechanisms of Antimicrobial Resistance in Pseudomonas aeruginosa: Our Worst Nightmare? Clin. Infect. Dis. 2002, 34, 634-640. [CrossRef]

23. Thomsen, T.; Mendel, H.; Al-Mansour, W.; Oddo, A.; Løbner-Olesen, A.; Hansen, P. Analogues of a Cyclic Antimicrobial Peptide with a Flexible Linker Show Promising Activity against Pseudomonas aeruginosa and Staphylococcus aureus. Antibiotics 2020, 9 , 366. [CrossRef] [PubMed]

24. Colque, C.A.; Albarracín Orio, A.G.; Feliziani, S.; Marvig, R.L.; Tobares, A.R.; Johansen, H.K.; Molin, S.; Smania, A.M. Hypermutator Pseudomonas aeruginosa Exploits Multiple Genetic Pathways to Develop Multidrug Resistance during Long-Term Infections in the Airways of Cystic Fibrosis Patients. Antimicrob. Agents Chemother. 2020, 64, e02142-19. [CrossRef] [PubMed]

25. Slizen, M.V.; Galzitskaya, O.V. Comparative Analysis of Proteomes of a Number of Nosocomial Pathogens by KEGG Modules and KEGG Pathways. Int. J. Mol. Sci. 2020, 21, 7839. [CrossRef]

26. Kurpe, S.; Grishin, S.; Surin, A.; Selivanova, O.; Fadeev, R.; Dzhus, U.; Gorbunova, E.; Mustaeva, L.; Azev, V.; Galzitskaya, O. Antimicrobial and Amyloidogenic Activity of Peptides Synthesized on the Basis of the Ribosomal S1 Protein from Thermus Thermophilus. Int. J. Mol. Sci. 2020, 21, 6382. [CrossRef]

27. Wang, Y.; Kadiyala, U.; Qu, Z.; Elvati, P.; Altheim, C.; Kotov, N.A.; Violi, A.; VanEpps, J.S. Anti-Biofilm Activity of Graphene Quantum Dots via Self-Assembly with Bacterial Amyloid Proteins. ACS Nano 2019, 13, 4278-4289. [CrossRef] [PubMed]

28. Kagan, B.L.; Jang, H.; Capone, R.; Teran Arce, F.; Ramachandran, S.; Lal, R.; Nussinov, R. Antimicrobial Properties of Amyloid Peptides. Mol. Pharm. 2012, 9, 708-717. [CrossRef]

29. Lee, E.Y.; Srinivasan, Y.; de Anda, J.; Nicastro, L.K.; Tükel, Ç.; Wong, G.C.L. Functional Reciprocity of Amyloids and Antimicrobial Peptides: Rethinking the Role of Supramolecular Assembly in Host Defense, Immune Activation, and Inflammation. Front. Immunol. 2020, 11, 1629. [CrossRef]

30. Wang, C.K.; King, G.J.; Conibear, A.C.; Ramos, M.C.; Chaousis, S.; Henriques, S.T.; Craik, D.J. Mirror Images of Antimicrobial Peptides Provide Reflections on Their Functions and Amyloidogenic Properties. J. Am. Chem. Soc. 2016, 138, 5706-5713. [CrossRef]

31. Vane, E.W.; He, S.; Maibaum, L.; Nath, A. Rapid Formation of Peptide/Lipid Coaggregates by the Amyloidogenic Seminal Peptide PAP248-286. Biophys. J. 2020, 119, 924-938. [CrossRef]

32. Kurpe, S.R.; Grishin, S.Y.; Surin, A.K.; Panfilov, A.V.; Slizen, M.V.; Chowdhury, S.D.; Galzitskaya, O.V. Antimicrobial and Amyloidogenic Activity of Peptides. Can Antimicrobial Peptides Be Used against SARS-CoV-2? Int. J. Mol. Sci. 2020, $21,9552$. [CrossRef] [PubMed]

33. Schramm, F.D.; Schroeder, K.; Jonas, K. Protein aggregation in bacteria. FEMS Microbiol. Rev. 2020, 44, 54-72. [CrossRef] [PubMed]

34. Giraldo, R. Optogenetic Navigation of Routes Leading to Protein Amyloidogenesis in Bacteria. J. Mol. Biol. 2019, 431, 1186-1202. [CrossRef]

35. Khodaparast, L.; Wu, G.; Khodaparast, L.; Schmidt, B.Z.; Rousseau, F.; Schymkowitz, J. Bacterial Protein Homeostasis Disruption as a Therapeutic Intervention. Front. Mol. Biosci. 2021, 8, 434. [CrossRef] 
36. Bednarska, N.G.; van Eldere, J.; Gallardo, R.; Ganesan, A.; Ramakers, M.; Vogel, I.; Baatsen, P.; Staes, A.; Goethals, M.; Hammarström, P.; et al. Protein aggregation as an antibiotic design strategy. Mol. Microbiol. 2016, 99, 849-865. [CrossRef]

37. Wu, G.; Khodaparast, L.; Khodaparast, L.; De Vleeschouwer, M.; Housmans, J.; Houben, B.; Schymkowitz, J.; Rousseau, F. Investigating the mechanism of action of aggregation-inducing antimicrobial Pept-ins. Cell Chem. Biol. 2021, 28, 524-536.e4. [CrossRef] [PubMed]

38. Matilla-Cuenca, L.; Toledo-Arana, A.; Valle, J. Anti-Biofilm Molecules Targeting Functional Amyloids. Antibiotics 2021, 10, 795. [CrossRef]

39. Jain, N.; Ådén, J.; Nagamatsu, K.; Evans, M.L.; Li, X.; McMichael, B.; Ivanova, M.I.; Almqvist, F.; Buxbaum, J.N.; Chapman, M.R. Inhibition of curli assembly and Escherichia coli biofilm formation by the human systemic amyloid precursor transthyretin. Proc. Natl. Acad. Sci. USA 2017, 114, 12184-12189. [CrossRef]

40. Sengupta, J.; Agrawal, R.K.; Frank, J. Visualization of protein S1 within the 30 S ribosomal subunit and its interaction with messenger RNA. Proc. Natl. Acad. Sci. USA 2001, 98, 11991-11996. [CrossRef]

41. Machulin, A.V.; Deryusheva, E.I.; Selivanova, O.M.; Galzitskaya, O.V. The number of domains in the ribosomal protein S1 as a hallmark of the phylogenetic grouping of bacteria. PLOS ONE 2019, 14, e0221370. [CrossRef]

42. Machulin, A.; Deryusheva, E.; Lobanov, M.; Galzitskaya, O. Repeats in S1 Proteins: Flexibility and Tendency for Intrinsic Disorder. Int. J. Mol. Sci. 2019, 20, 2377. [CrossRef]

43. Deryusheva, E.I.; Machulin, A.V.; Selivanova, O.M.; Galzitskaya, O.V. Taxonomic distribution, repeats, and functions of the S1 domain-containing proteins as members of the OB-fold family. Proteins Struct. Funct. Bioinforma 2017, 85, 602-613. [CrossRef]

44. Heinemann, U.; Roske, Y. Cold-Shock Domains-Abundance, Structure, Properties, and Nucleic-Acid Binding. Cancers 2021, 13, 190. [CrossRef] [PubMed]

45. Deryusheva, E.I.; Machulin, A.V.; Matyunin, M.A.; Galzitskaya, O.V. Investigation of the Relationship between the S1 Domain and Its Molecular Functions Derived from Studies of the Tertiary Structure. Molecules 2019, 24, 3681. [CrossRef]

46. Deryusheva, E.; Machulin, A.; Matyunin, M.; Galzitskaya, O. Sequence and evolutionary analysis of bacterial ribosomal S1 proteins. Proteins Struct. Funct. Bioinforma. 2021, 84, 1111-1124. [CrossRef] [PubMed]

47. Garbuzynskiy, S.O.; Lobanov, M.Y.; Galzitskaya, O.V. FoldAmyloid: A method of prediction of amyloidogenic regions from protein sequence. Bioinformatics 2010, 26, 326-332. [CrossRef]

48. Oliveberg, M. Waltz, an exciting new move in amyloid prediction. Nat. Methods 2010, 7, 187-188. [CrossRef]

49. Conchillo-Solé, O.; de Groot, N.S.; Avilés, F.X.; Vendrell, J.; Daura, X.; Ventura, S. AGGRESCAN: A server for the prediction and evaluation of "hot spots" of aggregation in polypeptides. BMC Bioinform. 2007, 8, 65. [CrossRef] [PubMed]

50. Walsh, I.; Seno, F.; Tosatto, S.C.E.; Trovato, A. PASTA 2.0: An improved server for protein aggregation prediction. Nucleic Acids Res. 2014, 42, W301-W307. [CrossRef]

51. Grishin, S.Y.; Dzhus, U.F.; Glukhov, A.S.; Selivanova, O.M.; Surin, A.K.; Galzitskaya, O.V. Identification of Amyloidogenic Regions in Pseudomonas aeruginosa Ribosomal S1 Protein. Int. J. Mol. Sci. 2021, 22, 7291. [CrossRef] [PubMed]

52. Zhang, Y.; Liu, Y.; Tang, Y.; Zhang, D.; He, H.; Wu, J.; Zheng, J. Antimicrobial $\alpha$-defensins as multi-target inhibitors against amyloid formation and microbial infection. Chem. Sci. 2021, 12, 9124-9139. [CrossRef] [PubMed]

53. Stepanenko, O.V.; Sulatsky, M.I.; Mikhailova, E.V.; Stepanenko, O.V.; Kuznetsova, I.M.; Turoverov, K.K.; Sulatskaya, A.I. Trypsin Induced Degradation of Amyloid Fibrils. Int. J. Mol. Sci. 2021, 22, 4828. [CrossRef] [PubMed]

54. Surin, A.K.; Grishin, S.Y.; Galzitskaya, O.V. Determination of amyloid core regions of insulin analogues fibrils. Prion 2020, 14, 149-162. [CrossRef]

55. Sarkar, T.; Chetia, M.; Chatterjee, S. Antimicrobial Peptides and Proteins: From Nature's Reservoir to the Laboratory and Beyond. Front. Chem. 2021, 9, 432. [CrossRef] [PubMed]

56. Wang, T.; Zou, C.; Wen, N.; Liu, X.; Meng, Z.; Feng, S.; Zheng, Z.; Meng, Q.; Wang, C. The effect of structural modification of antimicrobial peptides on their antimicrobial activity, hemolytic activity, and plasma stability. J. Pept. Sci. 2021, 27 , e3306. [CrossRef]

57. Chen, X.; Petranovic, D. Amyloid- $\beta$ peptide-induced cytotoxicity and mitochondrial dysfunction in yeast. FEMS Yeast Res. 2015, 15, fov061. [CrossRef]

58. Fakhranurova, L.; Balobanov, V.; Ryabova, N.; Glukhov, A.; Ilyina, N.; Markelova, N.; Marchenkov, V.; Katina, N. The presence of cross- $\beta$-structure as a key determinant of carbonic anhydrase amyloid fibrils cytotoxicity. Biochem. Biophys. Res. Commun. 2020, 524, 453-458. [CrossRef]

59. Zhang, Y.; Tang, Y.; Liu, Y.; Zhang, D.; Zheng, J. Design and Engineering of Amyloid Aggregation-Prone Fragments and Their Antimicrobial Conjugates with Multi-Target Functionality. Adv. Funct. Mater. 2021, 31, 2102978. [CrossRef]

60. Buccini, D.F.; Cardoso, M.H.; Franco, O.L. Antimicrobial Peptides and Cell-Penetrating Peptides for Treating Intracellular Bacterial Infections. Front. Cell. Infect. Microbiol. 2021, 10, 612931. [CrossRef]

61. Beyermann, M.; Henklein, P.; Klose, A.; Sohr, R.; Bienert, M. Effect of tertiary amine on the carbodiimide-mediated peptide synthesis. Int. J. Pept. Protein Res. 2009, 37, 252-256. [CrossRef]

62. $\mathrm{Wu}$, J.; Gao, B.; Zhu, S. Single-point mutation-mediated local amphipathic adjustment dramatically enhances antibacterial activity of a fungal defensin. FASEB J. 2016, 30, 2602-2614. [CrossRef] 
63. Gaglione, R.; Smaldone, G.; Cesaro, A.; Rumolo, M.; De Luca, M.; Di Girolamo, R.; Petraccone, L.; Del Vecchio, P.; Oliva, R.; Notomista, E.; et al. Impact of a Single Point Mutation on the Antimicrobial and Fibrillogenic Properties of Cryptides from Human Apolipoprotein B. Pharmaceuticals 2021, 14, 631. [CrossRef] [PubMed]

64. Yokoo, H.; Hirano, M.; Ohoka, N.; Misawa, T.; Demizu, Y. Structure-activity relationship study of amphipathic antimicrobial peptides using helix-destabilizing sarcosine. J. Pept. Sci. 2021, e3360. [CrossRef]

65. Drozdetskiy, A.; Cole, C.; Procter, J.; Barton, G.J. JPred4: A protein secondary structure prediction server. Nucleic Acids Res. 2015, 43, W389-W394. [CrossRef]

66. Rost, B.; Yachdav, G.; Liu, J. The PredictProtein server. Nucleic Acids Res. 2004, 32, W321-W326. [CrossRef] [PubMed]

67. Pirtskhalava, M.; Amstrong, A.A.; Grigolava, M.; Chubinidze, M.; Alimbarashvili, E.; Vishnepolsky, B.; Gabrielian, A.; Rosenthal, A.; Hurt, D.E.; Tartakovsky, M. DBAASP v3: Database of antimicrobial/cytotoxic activity and structure of peptides as a resource for development of new therapeutics. Nucleic Acids Res. 2021, 49, D288-D297. [CrossRef] [PubMed]

68. Pirtskhalava, M.; Vishnepolsky, B.; Grigolava, M.; Managadze, G. Physicochemical Features and Peculiarities of Interaction of AMP with the Membrane. Pharmaceuticals 2021, 14, 471. [CrossRef]

69. Pandit, G.; Chowdhury, N.; Abdul Mohid, S.; Bidkar, A.P.; Bhunia, A.; Chatterjee, S. Effect of Secondary Structure and Side Chain Length of Hydrophobic Amino Acid Residues on the Antimicrobial Activity and Toxicity of 14-Residue-Long de novo AMPs. ChemMedChem 2021, 16, 355-367. [CrossRef]

70. Wang, K.F.; Nagarajan, R.; Camesano, T.A. Differentiating antimicrobial peptides interacting with lipid bilayer: Molecular signatures derived from quartz crystal microbalance with dissipation monitoring. Biophys. Chem. 2015, 196, 53-67. [CrossRef]

71. Liu, Y.; Xia, X.; Xu, L.; Wang, Y. Design of hybrid $\beta$-hairpin peptides with enhanced cell specificity and potent anti-inflammatory activity. Biomaterials 2013, 34, 237-250. [CrossRef]

72. Frederiksen, N.; Hansen, P.R.; Zabicka, D.; Tomczak, M.; Urbas, M.; Domraceva, I.; Björkling, F.; Franzyk, H. Alternating Cationic-Hydrophobic Peptide/Peptoid Hybrids: Influence of Hydrophobicity on Antibacterial Activity and Cell Selectivity. ChemMedChem 2020, 15, 2544-2561. [CrossRef]

73. Gong, H.; Liao, M.; Hu, X.; Fa, K.; Phanphak, S.; Ciumac, D.; Hollowell, P.; Shen, K.; Clifton, L.A.; Campana, M.; et al. Aggregated Amphiphilic Antimicrobial Peptides Embedded in Bacterial Membranes. ACS Appl. Mater. Interfaces 2020, 12, 44420-44432. [CrossRef]

74. Dathe, M.; Meyer, J.; Beyermann, M.; Maul, B.; Hoischen, C.; Bienert, M. General aspects of peptide selectivity towards lipid bilayers and cell membranes studied by variation of the structural parameters of amphipathic helical model peptides. Biochim. Biophys. Acta Biomembr. 2002, 1558, 171-186. [CrossRef]

75. Meikle, T.G.; Dharmadana, D.; Hoffmann, S.V.; Jones, N.C.; Drummond, C.J.; Conn, C.E. Analysis of the structure, loading and activity of six antimicrobial peptides encapsulated in cubic phase lipid nanoparticles. J. Colloid Interface Sci. 2021, 587, 90-100. [CrossRef] [PubMed]

76. Souza, P.F.N.; Marques, L.S.M.; Oliveira, J.T.A.; Lima, P.G.; Dias, L.P.; Neto, N.A.S.; Lopes, F.E.S.; Sousa, J.S.; Silva, A.F.B.; Caneiro, R.F.; et al. Synthetic antimicrobial peptides: From choice of the best sequences to action mechanisms. Biochimie 2020, 175, 132-145. [CrossRef] [PubMed]

77. Singh, O.; Hsu, W.-L.; Su, E.C.-Y. Co-AMPpred for in silico-aided predictions of antimicrobial peptides by integrating compositionbased features. BMC Bioinform. 2021, 22, 389. [CrossRef]

78. Sheehan, D.J.; Janda, J.M.; Bottone, E.J. Pseudomonas aeruginosa: Changes in antibiotic susceptibility, enzymatic activity, and antigenicity among colonial morphotypes. J. Clin. Microbiol. 1982, 15, 926-930. [CrossRef]

79. Domnin, P.; Arkhipova, A.; Petrov, S.; Sysolyatina, E.; Parfenov, V.; Karalkin, P.; Mukhachev, A.; Gusarov, A.; Moisenovich, M.; Khesuani, Y.; et al. An In Vitro Model of Nonattached Biofilm-Like Bacterial Aggregates Based on Magnetic Levitation. Appl. Environ. Microbiol. 2020, 86, e01074-20. [CrossRef]

80. Soundrarajan, N.; Park, S.; Le Van Chanh, Q.; Cho, H.; Raghunathan, G.; Ahn, B.; Song, H.; Kim, J.-H.; Park, C. Protegrin-1 cytotoxicity towards mammalian cells positively correlates with the magnitude of conformational changes of the unfolded form upon cell interaction. Sci. Rep. 2019, 9, 11569. [CrossRef]

81. Grishin, S.Y.; Deryusheva, E.I.; Machulin, A.V.; Selivanova, O.M.; Glyakina, A.V.; Gorbunova, E.Y.; Mustaeva, L.G.; Azev, V.N.; Rekstina, V.V.; Kalebina, T.S.; et al. Amyloidogenic Propensities of Ribosomal S1 Proteins: Bioinformatics Screening and Experimental Checking. Int. J. Mol. Sci. 2020, 21, 5199. [CrossRef]

82. Vasilchenko, A.S.; Vasilchenko, A.V.; Valyshev, A.V.; Rogozhin, E.A. A Novel High-Molecular-Mass Bacteriocin Produced by Enterococcus faecium: Biochemical Features and Mode of Action. Probiotics Antimicrob. Proteins 2018, 10, 427-434. [CrossRef] [PubMed]

83. Suvorina, M.Y.; Selivanova, O.M.; Grigorashvili, E.I.; Nikulin, A.D.; Marchenkov, V.V.; Surin, A.K.; Galzitskaya, O.V. Studies of Polymorphism of Amyloid- $\beta 42$ Peptide from Different Suppliers. J. Alzheimer's Dis. 2015, 47, 583-593. [CrossRef] [PubMed]

84. Stefani, M. Biochemical and biophysical features of both oligomer/fibril and cell membrane in amyloid cytotoxicity. FEBS J. 2010, 277, 4602-4613. [CrossRef]

85. Mwangi, J.; Yin, Y.; Wang, G.; Yang, M.; Li, Y.; Zhang, Z.; Lai, R. The antimicrobial peptide ZY4 combats multidrug-resistant Pseudomonas aeruginosa and Acinetobacter baumannii infection. Proc. Natl. Acad. Sci. USA 2019, 116, 26516-26522. [CrossRef]

86. Yasir, M.; Dutta, D.; Willcox, M.D.P. Comparative mode of action of the antimicrobial peptide melimine and its derivative Mel4 against Pseudomonas aeruginosa. Sci. Rep. 2019, 9, 7063. [CrossRef] [PubMed] 
87. Yasir, M.; Dutta, D.; Hossain, K.R.; Chen, R.; Ho, K.K.K.; Kuppusamy, R.; Clarke, R.J.; Kumar, N.; Willcox, M.D.P. Mechanism of Action of Surface Immobilized Antimicrobial Peptides Against Pseudomonas aeruginosa. Front. Microbiol. 2020, $10,3053$. [CrossRef] [PubMed]

88. Bernhofer, M.; Dallago, C.; Karl, T.; Satagopam, V.; Heinzinger, M.; Littmann, M.; Olenyi, T.; Qiu, J.; Schütze, K.; Yachdav, G.; et al. PredictProtein-Predicting Protein Structure and Function for 29 Years. bioRxiv 2021. [CrossRef]

89. Moon, C.P.; Fleming, K.G. Side-chain hydrophobicity scale derived from transmembrane protein folding into lipid bilayers. Proc. Natl. Acad. Sci. USA 2011, 108, 10174-10177. [CrossRef] [PubMed]

90. Waghu, F.H.; Gopi, L.; Barai, R.S.; Ramteke, P.; Nizami, B.; Idicula-Thomas, S. CAMP: Collection of sequences and structures of antimicrobial peptides. Nucleic Acids Res. 2014, 42, D1154-D1158. [CrossRef]

91. Kurpe, S.R.; Grishin, S.Y.; Glyakina, A.V.; Slizen, M.V.; Panfilov, A.V.; Kochetov, A.P.; Surin, A.K.; Kobyakova, M.I.; Fadeev, R.S.; Galzitskaya, O.V. Antibacterial effects of peptides synthesized based on the sequence of ribosome protein S1. Biomed. Khim. 2021, 67, 231-243. [CrossRef] [PubMed] 